\title{
Sustained by First Nations: European newcomers' use of Indigenous plant foods in temperate North America
}

\author{
Nancy Jean Turner ${ }^{1 *}$, Patrick von Aderkas ${ }^{2}$ \\ 'School of Environmental Studies, University of Victoria, PO Box 3060 STN CSC, Victoria, BC V8W 3R4, Canada \\ ${ }^{2}$ Department of Biology, University of Victoria, PO Box 3060 STN CSV, Victoria, BC V8W 3R4, Canada
}

\section{Abstract}

Indigenous Peoples of North America have collectively used approximately 1800 different native species of plants, algae, lichens and fungi as food. When European explorers, traders and settlers arrived on the continent, these native foods, often identified and offered by Indigenous hosts, gave them sustenance and in some cases saved them from starvation. Over the years, some of these species - particularly various types of berries, such as blueberries and cranberries (Vaccinium spp.), wild raspberries and blackberries (Rubus spp.), and wild strawberries (Fragaria spp.), and various types of nuts (Corylus spp., Carya spp., Juglans spp., Pinus spp.), along with wild-rice (Zizania spp.) and maple syrup (from Acer saccharum) - became more widely adopted and remain in use to the present day. Some of these and some other species were used in plant breeding programs, as germplasm for hybridization programs, or to strengthen a crop's resistance to disease. At the same time, many nutritious Indigenous foods fell out of use among Indigenous Peoples themselves, and along with their lessened use came a loss of associated knowledge and cultural identity. Today, for a variety of reasons, from improving people's health and regaining their cultural heritage, to enhancing dietary diversity and enjoyment of diverse foods, some of the species that have dwindled in their use have been "rediscovered" by Indigenous and non-Indigenous Peoples, and indications are that their benefits to humanity will continue into the future.

Keywords: ethnobotany, wild food plants, North America, European settlers, edible wild plants

\section{Introduction}

Many world-class food products originated in the Americas: maize (Zea mays), potatoes (Solanum tuberosum), beans (Phaseolus vulgaris), peppers (Capsicum annuum), tomatoes (Lycopersicum esculentum), pineapples (Ananas comosa), papayas (Carica papaya), chocolate (Theobroma cacao) and vanilla (Vanilla planifolia), to name just a few. Most of these were introduced to Europe fairly early on by explorers like Christopher Columbus, and all of these examples were crops that were domesticated originally from Central and South America. However, North American Indigenous Peoples have relied for millennia on diverse and nutritious plant foods from their own and neighbouring territories. Among these, only a handful, most notably sunflower (Helianthus annuus), have spread worldwide as domesticated crops. Many others, including wild-growing and locally cultivated species, have been consumed and enjoyed more on a regional scale, not only by

\footnotetext{
* Corresponding author. Email: nturner@uvic.ca
}

This is an Open Access digital version of the article distributed under the terms of the Creative Commons Attribution 3.0 License (creativecommons.org/licenses/by/3.0/), which permits redistribution, commercial and non-commercial, provided that the article is properly cited.
First Peoples, but by newcomer populations during the trade and colonial eras, and right up to the present day as people everywhere have reclaimed their interest in local, sustainable food systems [1]. In this paper, we focus on plant foods of North American First Peoples that were adopted in earlier times by Europeans and other immigrants, in some cases out of necessity, but also because of convenience and appreciation of their quality, taste and nutritive values. To provide a deeper understanding of the types of situations in which these foods were adopted, we highlight six key species of North American edible wild plants, with details of their procurement, acceptance and adaptation by the European newcomers, including their use up to the present time.

North American First Peoples were known to have used, collectively, somewhere in the neighbourhood of 1800 species as sources of food and beverages [2]. Here we provide an inventory of those most commonly known to have been shared with newcomers, and we focus on the era of exploration and settlement of the continent by Europeans and other non-Indigenous populations, rather than on the more recent harvesting and use of such foods within the past half century or so, as highlighted by authors such as Fernald and Kinsey [3], Euell Gibbons [4], Erika Gaertner [5,6], Szczawinski and Turner [7] and Turner and Szczawinski $[8,9]$, Thayer [10,11], and Kallas [12]. Some of these foods are also featured products of the Slow Food organization, dedicated to preserving the biodiversity and cultural values of the world's foods [13]. 
Records of earlier use and adoption of Indigenous North American foods by newcomers are found in many sources, including diaries and journals of early explorers like Captain James Cook [14]; Simon Fraser [15] and Meriwether Lewis and William Clark [16]. Many of these people would not have survived without the help and provisions offered by the First Peoples then encountered along their routes. Diaries and accounts of early settlers like Susan Allison [17] also sometimes refer to their adoption of indigenous plant foods, and ethnographic accounts, local pioneer histories and other sources also contribute such information $[18,19]$. Examining the names of plant species used, by both First Nations and newcomers, can also give clues about the adoption and use of these foods by the latter. For example, the fact that there is a name in Chinook Jargon, a hybrid trade language, for camas - le camas (with the French article "le") - indicates that traders and newcomers were conversing about this plant, and probably about its use in trade and commerce. Other literature sources back up this suggestion [20,21].

One aspect of traditional plant food use by Indigenous Peoples was not well recognized or appreciated by the newcomer populations, namely Indigenous tending and management of many different species and habitats, to promote and sustain the growth and productivity of plant resources [22-24]. In northwestern North America, for example, the Indigenous Peoples have long been characterized as "hunter-gatherers", whose use of plants was considered to be, at best, somewhat random and casual. This allowed the colonial officials and settlers to make the convenient assumption that Indigenous people of the region needed very little land, for their sustenance, and that, as long as they had access to the rivers and oceans for fishing and shellfish harvesting, and to some forested areas for hunting, they would be able to survive. At the same time, the missionaries and colonial officials of the day set about to convert the First Nations to a "proper" farming economy, using the more recognized style of European agriculture, with potatoes, onions, turnips and domesticated fruits, introduced from outside the region $[20,24,25]$.

In any case, the Indigenous Peoples throughout North America were widely regarded as "primitive," and "savage". Their foods and lifestyles were seen by many people in this light, and there was an assumption of European superiority, even as the newcomers were relying on the very products they were disparaging. Explorer and botanist Robert Brown [26] epitomized these assumptions and attitudes in his description of Indigenous Peoples of northwestern North America whom he encountered in his travels: "The Indians are not much of a phytophagous (plant-eating) people. The tribes in the interior live by hunting, and those on the banks of great rivers, such as the Fraser and Columbia, chiefly by fishing, so that they only resort to vegetable diet as an addition to their ordinary food, or as a corrective to the unvarying meals of flesh and fish, chiefly venison and salmon. It is only the miserable Digger Indians the gens de pitie of the voyageurs - who can be said to subsist to any great extent on vegetable food, varying it with grubs, snakes, lizards, and grasshoppers, the latter of which they devour as eagerly as do the Bedouins of the Eastern deserts" [26].

Despite the disdain shown to some of the indigenous plant foods and to those who used them, many of these same species were not only sanctioned by the newcomers but embraced and incorporated into their everyday diets. Some species that were eaten by Native North Americans and by colonists alike, but never became more than locally popular or were restricted to wild harvest have received more attention recently as sources of genetic material for crop development.

Medicinal plants used by First Nations were taken up selectively by the colonists and in effect, continue to be taken up by their descendants. However, this movement of species was not solely of species naturally distributed in North America. Native North Americans had extensive trade networks that had been operating for millennia. The tobacco species Nicotiana rustica, which is native to Central and South America was introduced to the northeast more than a millennium prior to the arrival of Europeans. Although it was rapidly adopted by early colonists, who even grew it for export, N. rustica was replaced by $N$. tabacum, which had less nicotine but a more desirable taste. In the 1990s, a hybrid between the two species was created. Named Y1, it was much richer in nicotine than other varieties. It became the source of much controversy, until its development was abandoned later in the decade. This example illustrates that food or medicine plants that have attracted a lot of human attention will continue to be targets for drugs, compounds and genes for future breeding programs.

Of course, the newcomers brought many species from Europe and elsewhere that were adopted into the diets and medicinal pharmacopoeias of Indigenous Peoples. One example is horehound (Marrubium vulgare), which as explained by Chestnut [27]: "Where introduced and where the Indians came in contact with the white settlers, they used it in a like manner for colds and to stop diarrhea". Stinging nettle (Urtica dioica) is another species, which although native to North America as well as to Europe, evidently was introduced to Native Americans as an edible cooked green by Europeans. Indigenous Peoples have long used nettles as a source of tough fibre for cordage, lines and nets, and as medicine for many purposes, but apparently did not use it as a food before Europeans and Asian immigrants arrived [28,29]. Nettles soon became popular as a cooked green, used by Iroquois, and various western Indigenous Peoples including Straits Salish, Halkomelem, Sechelt, Nlaka'pamux and others [29-32]. Another food apparently brought or adopted by Viking colonists in the distant past, but evidently not used by the Indigenous Peoples, is sea lyme grass, or strand-wheat [Leymus arenarius (L.) Hochst.] [33].

\section{Indigenous plant foods and use by newcomers}

As early as $1000 \mathrm{AD}$, the Beothuk of Newfoundland and other Native North Americans were in frequent contact with Europeans and Scandinavians [19]. The most celebrated "first contact" by Europeans, however, was in 1492, with Christopher Columbus, who sailed for King Ferdinand II and Queen Isabella of Spain, and travelled to the Caribbean. He was followed shortly by a number of other celebrated explorers: in 1497 John Cabot voyaged to "New-found-land" from England; in 1524 Jacques Cartier made his famous ventures up the St. Lawrence River; and by the mid-16th Century European fishermen were travelling annually to the east coast of North America, and Francisco Vásquez de Coronado, a Spanish explorer and conquistador became the first European to explore North America's Southwest. Driven by desire for discovery and wealth, other explorers, French, English and Spanish, ventured to many other parts of the continent in the decades that followed. Arrival of Europeans on the West Coast of North America came later, with Russians (under Danish Navigator 
Vitus Bering) entering from the north and Spaniards and English from the south, starting in the mid-1700s.

Many of these explorers benefited from Indigenous Peoples' knowledge and generosity, and in some cases, they would have perished without this assistance. For example, at "Hochelaga", the site on the St. Lawrence River near what is now the City of Montreal, Jacques Cartier and his men overwintered, icebound, were brought Eastern White Cedar (Thuja occidentalis) by the local Indigenous people who showed the weakened and dying men how to make an antiscorbutic tea by boiling the bark and foliage, thereby saving all who partook of it from a terrible death by scurvy (vitamin C deficiency). A grateful Cartier labeled this tree "arbre de vie", or "tree of life" [8]. Later, in 1778, when Captain James Cook anchored at Nootka Sound on the west coast of Vancouver Island, his men noticed wild nodding onions, or "wild garlick" (Allium cernuum), growing in profusion along the bluffs near the sea. The local Nuu-chahnulth brought them to sell to the men [14]. Scottish-born fur trader and explorer Alexander Mackenzie, who travelled with his men in 1793 across the Rocky Mountains to the Pacific Ocean in what is now British Columbia routinely mixed wild onions (Allium schoenoprasum) with their dried meat - "a great improvement of it..." They also roasted the tender young shoots of "wild parsnip" (cow-parsnip, Heracleum maximum; Fig. 1), over the fire, and found them, when peeled, to be "a very palatable food" [34]. These foods were evidently learned from local First Peoples. Another explorer who wrote about foods received from Indigenous people was Simon Fraser, who explored and mapped the interior of British Columbia and the Plateau region in 1808. Fraser's expedition down the river that now bears his name brought him in contact with a number of First Nations, including the Nlaka'pamux and Secwepemc, "kindly and courteous" Interior Salish peoples who gave Fraser and his men abundant salmon, dried berries, oil and roots of several kinds including wild onions (Allium cernuum) [14].

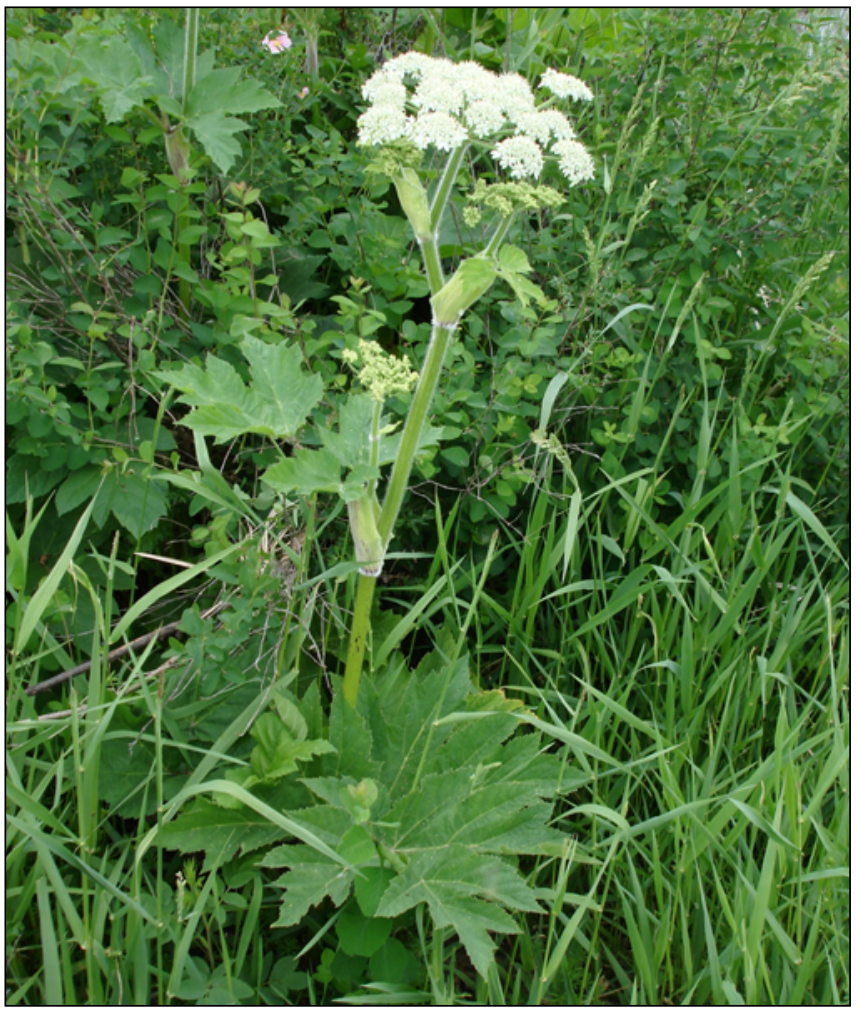

Fig. 1 Cow-parsnip, Heracleum maximum.
Lichens such as rock tripe (Umbilicaria spp., Actinogyra spp.) were a particular emergency food, known to Cree, Chipewyan and other Indigenous Indian and to Inuit peoples as a "fall back" in times of famine. They were adopted in times of extreme food shortage by explorers such as Sir John Franklin and Sir John Richardson and by French Canadian Jesuit Fathers and voyageurs, but were by no means considered prime food [33].

As well as benefitting from the maize (Zea mays), squash (Cucurbita spp.) and other crops grown by agrarian Indigenous Peoples in their gardens, early European explorers enjoyed nuts like hickory and pecans, and described groves near Indian villages where nut trees were managed as "orchards" [35]. Hazelnuts (Corylus spp.) were another type of nut that traders, and later settlers, enjoyed, but few people adopted the use of acorns, which required special preparation to reduce their bitterness [36]. Trading Fort personnel, who were established in one place for a long period of time, rather than simply moving through an area, were particularly aided through trade with local First Peoples for foodstuffs, including potatoes (Solanum tuberosum), which had been originally brought onto the west coast of North America by the earliest Spaniards and were soon being produced up and down the coast and traded in large quantities to Indigenous and non-Indigenous neighbours alike [37]. The traders, in turn, provided the Indigenous Peoples with new products like beans, rice, molasses and sugar, and tea. Foods that the fur traders routinely obtained from local First Peoples included camas bulbs (Camassia spp.), wapato (Sagittaria spp.; Fig. 2, Fig. 3, Fig. 4), saskatoonberries (Amelanchier alnifolia), cranberries (Vaccinium spp.) and wild-rice (Zizania spp.), along with salmon and game [38].

Brown [26] provided an excellent description of the preparation and use of soapberries (Shepherdia canadensis; Fig. 5, Fig. 6), which he erroneously referred to as "One of the Vacciniums", which "... is well known to all North-Western travellers (at least those who have been much among the Northern Indians) as the "le brou" plant, being used to make a dainty of that name. The berries are gathered in the autumn, before they are quite ripe; and after being pressed into a cake, are dried and wrapped in bark, and laid by. When the cake is to be used, a quantity is put into a vessel among cold water, and then stirred rapidly round with the hand, which must be free from grease, until it assumes a paste-like form. More water is added, and more stirring applied, until it assumes a form not unlike soap-suds. In this frothy state it is supped with long wooden spoons (made of Pinus monticola). It is pleasant to the taste, with a slightly bitter flavor, and is often prepared in Hudson's Bay forts as an Indian dish which no traveller ought to leave the Northwest without tasting".

Richardson [39] described another use for soapberry: its juicy red and very bitter berries were used to make a kind of beer, said to ferment in 24 hours, and to be an agreeable beverage in hot weather [34].

As well as adopting new foods in the new places they entered, traders and explorers also brought indigenous products from other places and introduced them more widely. The practice of smoking kinnikinnick (Arctostaphylos uva-ursi) leaves was evidently learned from Algonkian peoples, then brought by traders across to western North America [8,26]. Using Labrador-tea (Rhododendron groenlandicum) leaves for tea was a practice of Hudson's Bay Company and other fur traders, again apparently learned about from eastern First Nations. Hudson's Bay Company servants used this tea and some 


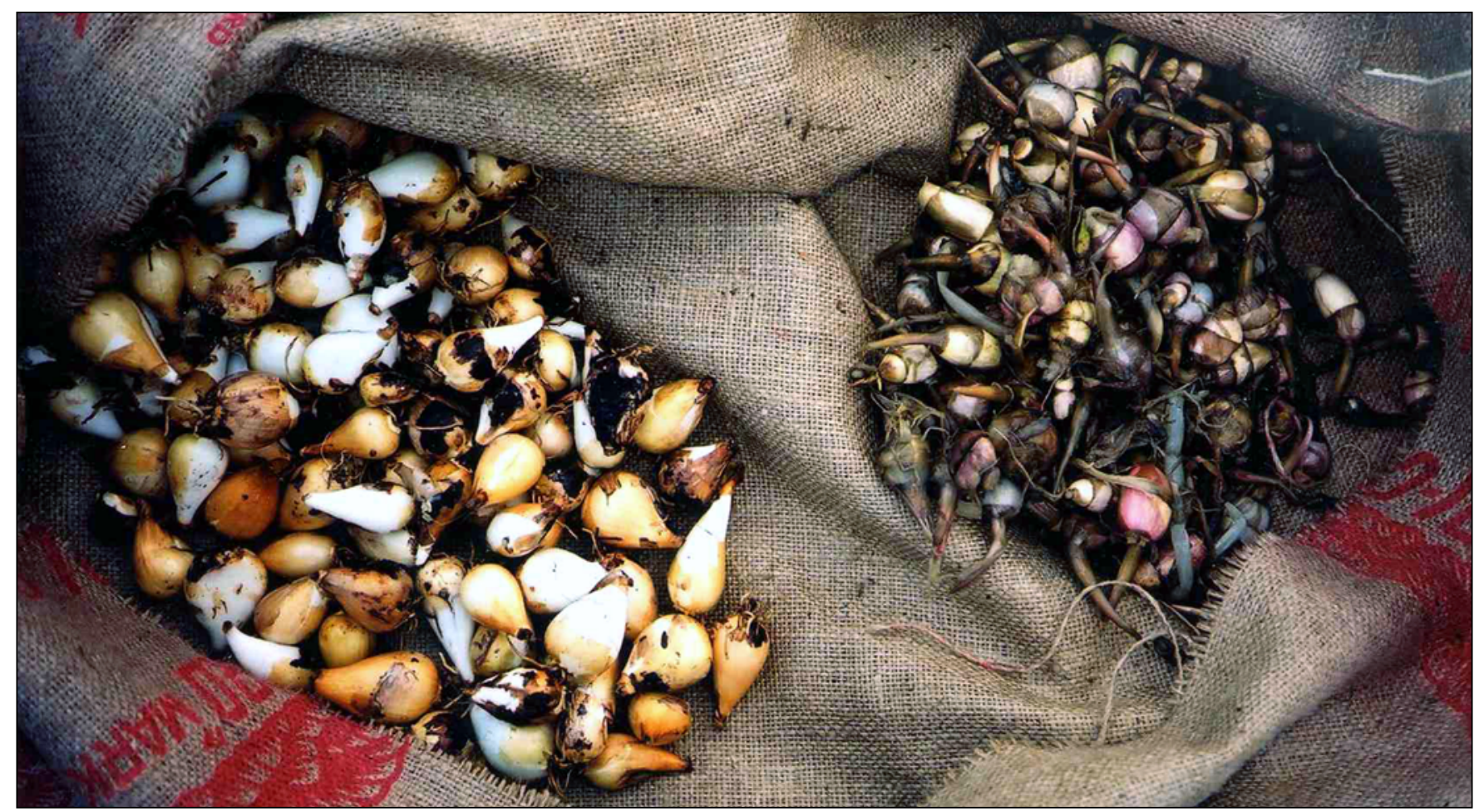

Fig. 2 Camas bulbs (Camassia quamash; left) and wapato tubers (Sagittaria latifolia; right).

thought it very pleasant, according to Samuel Hearne $[33,40]$. The Company officials then evidently introduced the practice to some of the western First Nations [8,32-34]. Stinging nettle (Urticia dioica), mentioned earlier, was another plant whose edibility was identified by newcomers, then adopted by First Peoples, who were already familiar with this plant as a source of fibre and medicine.

One example of a Trading Post in which Indigenous food played a significant role was Fort Langley, established in 1827 on the Lower Fraser River, near the junction of the Fraser and Salmon Rivers. This Hudson's Bay Company fort was established to secure a HBC presence along the Pacific Coast, an area previously monopolized by American traders. Not only fur trading but also agriculture and salmon fishing were conducted at Fort Langley and, as settlers entered the region, it served as a sales shop for them, until it closed in 1896. The

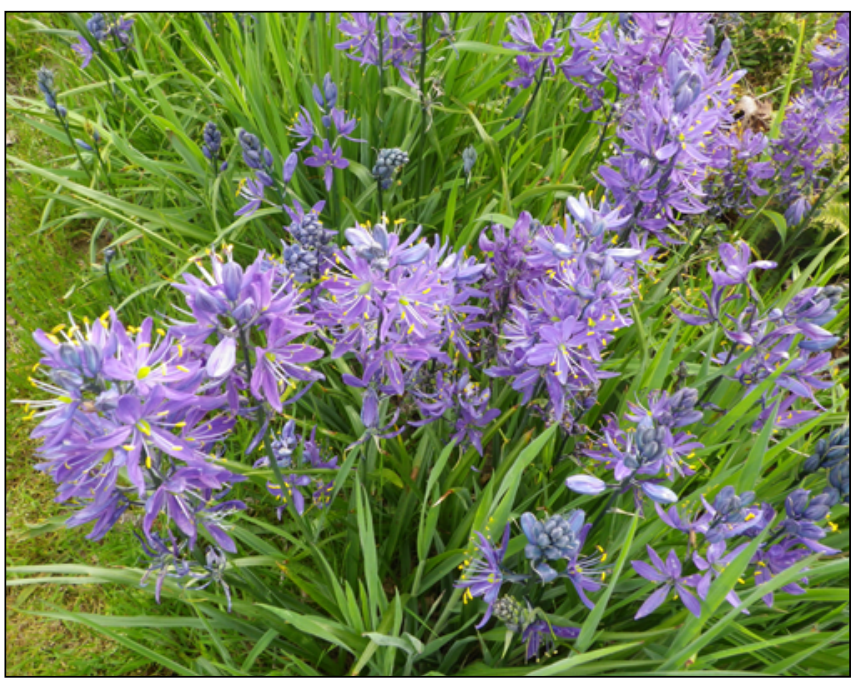

Fig. 3 Camas flowers (Camassia quamash). role of the fort in the use and trading of bog cranberries is described later.

Trading posts like Fort Langley became local centres of new colonialist networks across North America. Settlers, too, quickly adopted a whole range of Indigenous foods, mostly learned about or purchased from local First Peoples [41] as well as from trading post personnel. "Some of the berries [of the Pacific Northwest], such as the strawberries (Fragaria vesca, F. virginiana and F. chiloensis; Fig. 7), will not admit of being dried, and are accordingly eaten fresh, or brought down to the frontier settlements and towns, and there sold to the whites..." [26]. Many other types of berries, from evergreen huckleberries (Vaccinium ovatum) to trailing blackberries (Rubus ursinus; Fig. 8) and wild raspberries (Rubus idaeus) were readily adopted into the diets of newcomers [32,36]. American wild plums (Prunus americana, P. nigra), eaten by

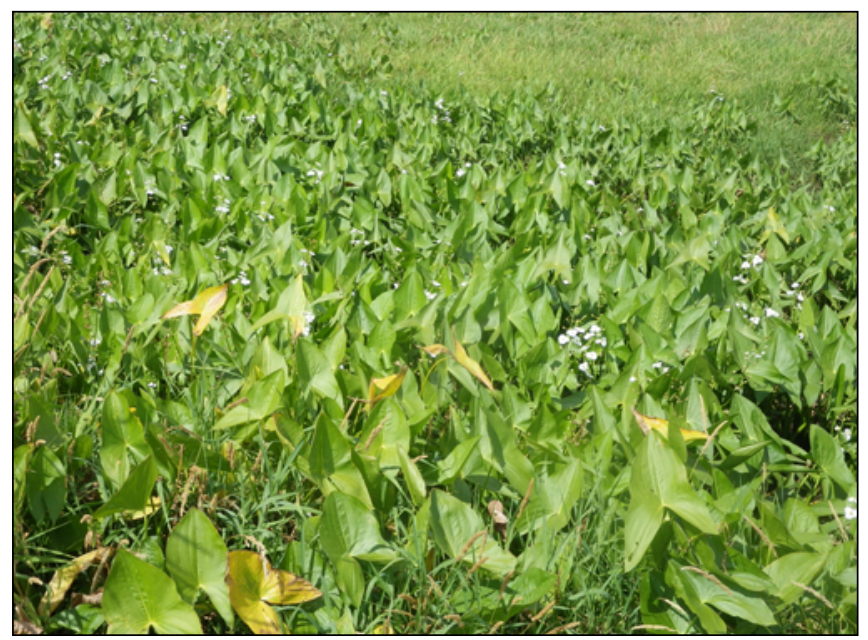

Fig. 4 Wapato (Sagittaria latifolia) growing along the Columbia River, Oregon. 
the Iroquois, Ojibwa, Mi'kmaq, Malecite, Pawnee, Cheyenne and other Indigenous groups, were also widely adopted and used by early explorers and settlers, and are the predecessor of several cultivated plum varieties [19,33,42].

Sometimes immigrants of special groups, such as Dukobour and Mennonite communities, people became major users and producers of some Indigenous foods. Waves of settlers, each with different food preferences, might arrive in an area one after another. For example, the first pioneers to settle in the Skagit River area of Washington State arrived around 1859, primarily from New England and Middle Atlantic states. They were followed by settlers from Carolinas, then Swedish and Norwegian immigrants, and lastly, people from Italy, British Isles, Germany, Greece and other parts of the United States [41]. Many Chinese settlers arrived during the construction of the transcontinental railways in the mid to late 1800 s, and they, too, had preferences for certain foods. Trading of wapato tubers (Sagittaria latifolia - Fig. 2) by Chinese immigrants along the Columbia River was recorded from 1865 in "The Oregonian": "Wapatos - the Kloochmen and Siwashes [sic: Chinook Jargon for women and Native Americans respectively] in this vicinity are just now in their element, the season having arrived for digging wapatos which they barter to the Celestial citizens [the Chinese] for a fair price. The trade is said to have been carried on very extensively between them and the aboriginal population during the past week" (Apr 14, 1865) $[36,43]$. Chinese and other Asian immigrants also often bought edible seaweed (Porphyra spp.) from coastal First Peoples. Some Indigenous People on southern Vancouver Island, for example, earned a living by picking this seaweed for sale to Chinese merchants, where it could bring up to $\$ 10$ per $\mathrm{kg}[33,44]$.

The settlers also brought their own food knowledge, sometimes recognizing species from their homelands, or growing plants from seed they had imported. In some cases, they shared these foods with the First Peoples. Many Russian immigrants, for example, already knew about the edibility of cattail (Typha latifolia) shoots (known to some as "Cossack asparagus"), stinging nettle (Urtica dioica), cow-parsnip (Heracleum maximum) and false Solomon's seal (Maianthemum racemosum). Scandinavians and British knew about the edibility of glasswort or samphire (Salicornia virginica), dulse (Palmaria palmata), cloudberry (Rubus chamaemorus) and lingonberry (Vaccinium vitis-idaea), among other species, and adopted these wherever they grew [40]. The settlers also introduced new ways of processing these different foods, from pickling to jarring or canning, or storing in crocks or casks, and these methods were quickly adopted by the First Peoples [33]. New recipes incorporating new foods were also developed. For example Kwakwaka'wakw, who had always enjoyed edible seaweed (Porphyra abbottiae) as a nutritious food, learned to prepare it in a new way, by mixing it with canned creamed corn, after this marketed food was introduced [44].

Sometimes, as a new food was adopted, it would be named after a more familiar food. An obvious example is the name "wild-rice" for Zizania, giving it some standing for people familiar with rice (Oryza sativa). On the other hand, new foods for Indigenous Peoples were also given names indicating similarity to known foods. Figs (Ficus carica), for instance, were called "resembling camas bulbs", and rice was called "resembling maggots", in Nuu-chah-nutlh [45].

Not only did European settlers eat many indigenous foods, but they also fed their livestock with native edible plants, often degrading these resources and causing resentment to

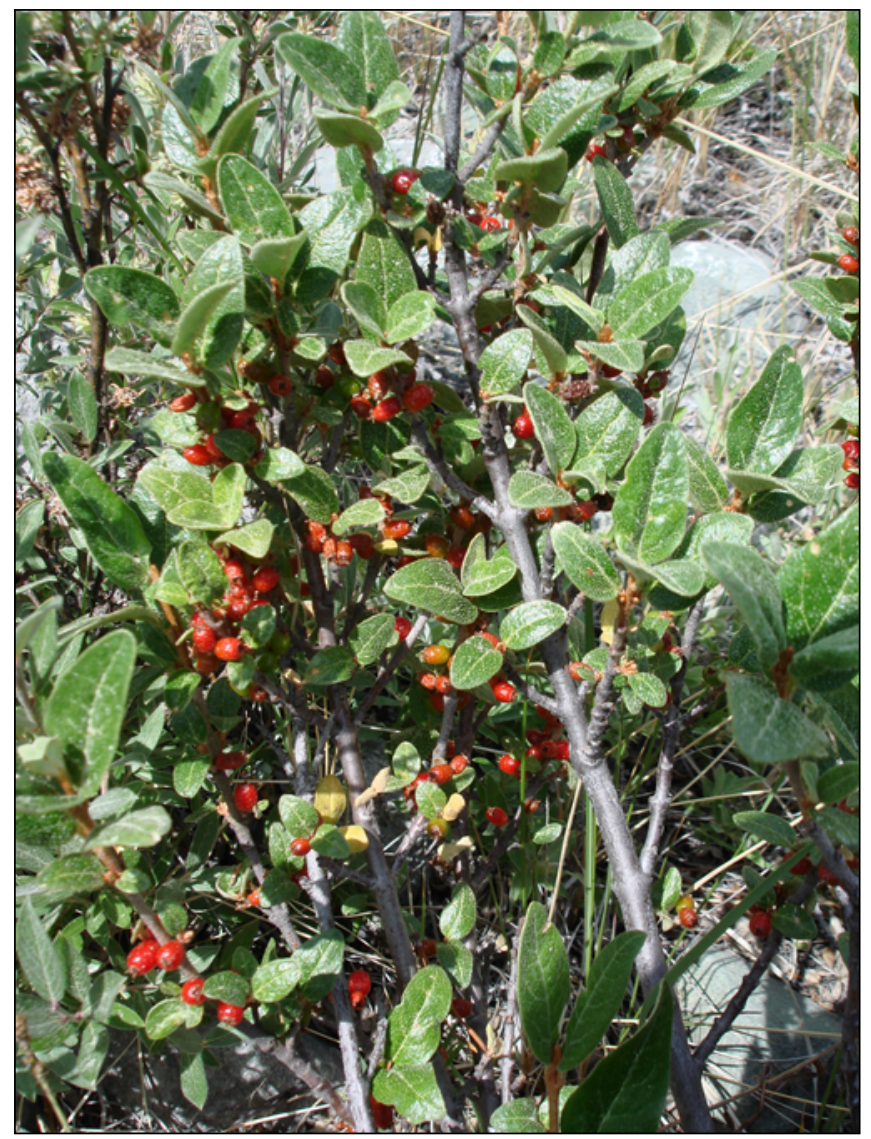

Fig. 5 Soapberries (Shepherdia canadensis).

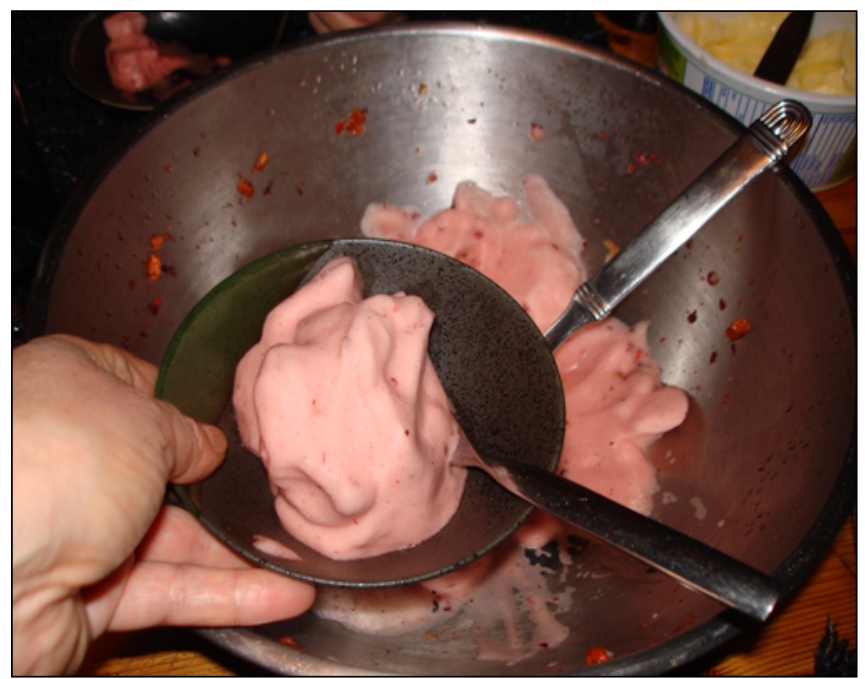

Fig. 6 Whip made of soapberries, a culturally important confection for Indigenous Peoples of western Canada.

the Indigenous Peoples who relied on them. For example, on southern Vancouver Island and elsewhere, settlers often fattened their pigs on camas bulbs, and ended up destroying many of the prime camas beds in the process [46]. Gibbs [47] noted that a drove of hogs belonging to one white man will consume the winter provision of a tribe of Indians.

\section{Medicines and materials}

As well as foodstuffs, traditional materials and technologies, and herbal medicines were also adopted from Indigenous 


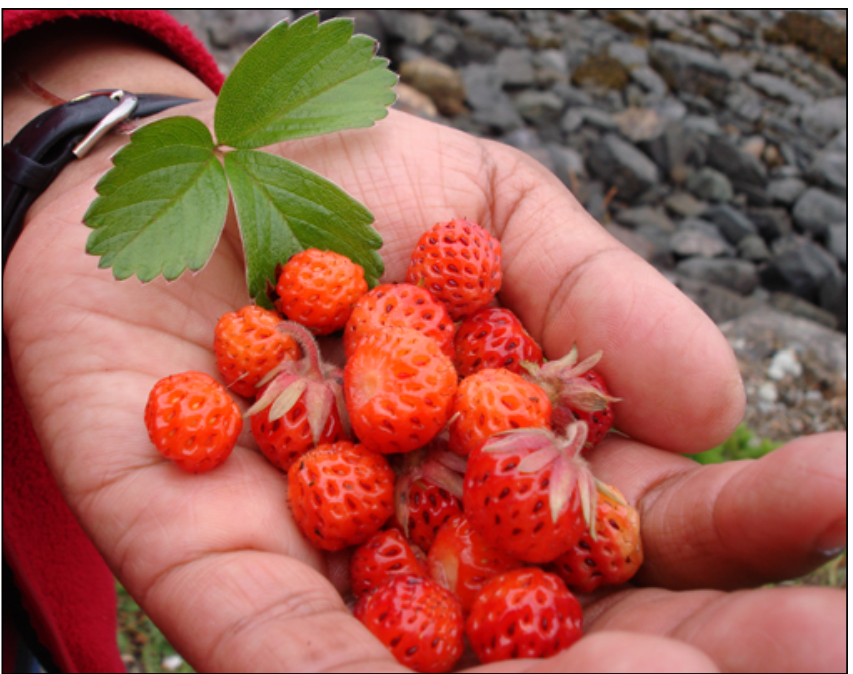

Fig. 7 Seaside strawberries (Fragaria chiloensis), one of the ancestral species of cultivated strawberries.

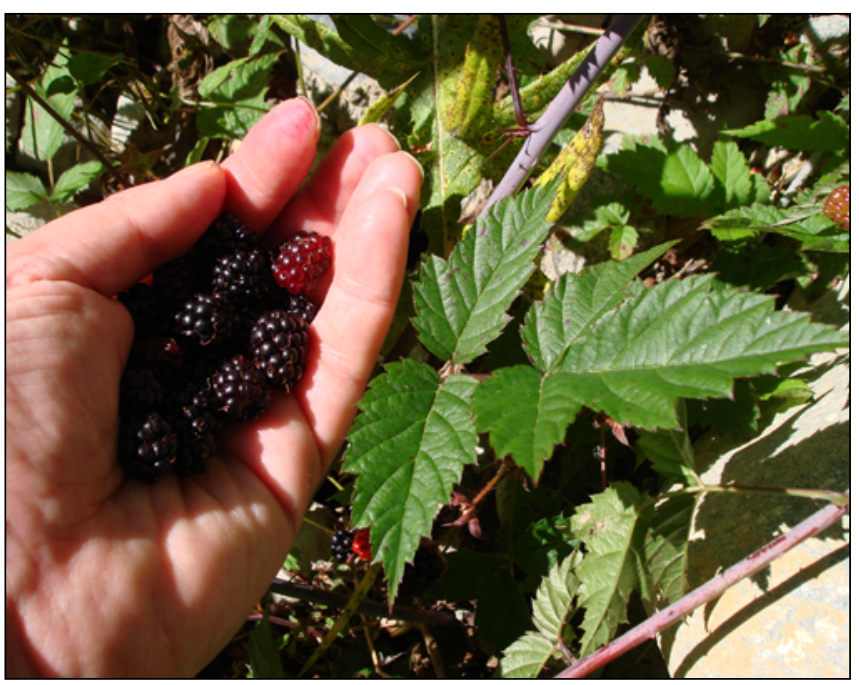

Fig. 8 Trailing wild blackberries (Rubus ursinus), one of the ancestral species of boysenberries and other cultivated varieties.

Peoples by explorers, traders and settlers. The newcomers bought baskets, bowls, canoes, and many other items from their Indigenous neighbours. For example, in the 1860 s pioneer woman of British Columbia, Susan Allison, wrote in her diary [17]: "Adjoining Hope [on the Fraser River] was an Indian Village, one very long house containing several families.... The Indians made baskets, blankets, and rugs.... The Baskets were very costly and were useful as well as pretty. They were watertight and took a long time to make, some of them months even of hard work; they were used for many purposes.... The Blankets they made from the hair of their dogs - and wove many pretty patterns in them by dyeing them with native roots and herbs".

First Nations women in particular benefited from being able to sell their baskets to White settler women [48].

Medicinal remedies were, like Indigenous foods, sometimes critical to the survival of European newcomers, and many were adopted by explorers, traders, and settlers, and became the basis of a widespread pharmacopoeia of herbal medicine (Tab. 1).
We do not discuss food plants used as medicine per se here, but it is worth noting that food plants and medicine plants lie along a continuum ranging from harmless to deadly. An example of a completely harmless plant product used in medicine was maple syrup, which was used to boil herb medicines in a bid to make them more palatable for children. At the other end of the scale were plants such as wild tobacco, Nicotiana rustica, which could not be eaten as it was poisonous when ingested, but not poisonous when smoked. Native North Americans smoked not only tobacco, but many kinds of medicinal plants. Plants that were poisonous were often used as emetics and purgatives, thereby curing ailments due to gastrointestinal problems, such as constipation, or even preventing poisoning after ingesting toxic plants. For example, hemp dogbane (Apocynum cannabinum) was used as a purgative by the Iroquois. Should someone have mistakenly consumed rootstocks of the extremely toxic but tasty water hemlock (Cicuta maculata), then elder root bark (Sambucus sp.) was given as powerful emetic [49]. Measuring the correct dosage of such poisonous plants was well understood. Just as eating the wrong thing could lead to trouble, not getting enough of the right foods could cause scurvy. Fresh food, in particular, vegetables could be in short supply during winter. To prevent scurvy, a drink was made of vitamin C-rich needles of spruce or hemlock.

Although the North American materia medica extensively relied on European herbal medicines, in some places such Ile aux Coudres in Quebec, a folk medicine developed over the centuries that mixed First Nations' and colonists' medicine [50]. Although mainstream medicine, like mainstream culinary practice, adopted only a selection of the plants used by First Nations [2,51], a recent example shows that this process of adoption continues. In the Pacific Northwest, First Nations used berries, bark and foliage of Pacific yew (Taxus brevifolia) to treat rheumatism and internal illnesses. The taxane compounds in the bark were found to be effective against ovarian and cervical cancer. During the 1990s this tree was heavily exploited as trials were conducted that led to improved treatments and more efficient chemical manufacture. Pacific yew breeding programs were initiated, but eventually, the pharmaceutical industry turned to cultivated species of yew for feedstocks, thereby sparing Pacific yew trees from extirpation [52].

\section{Plant foods and their adoption by European newcomers}

In all, some 1800 species of plants indigenous to North America were - and many still are - used as foods or beverages by First Peoples in one or more places across the continent. Many of these are known to have been adopted and used by European and other immigrants to the continent as survival foods, or in some cases as staples. Tab. 2 lists some key examples of these latter species.

\section{Case examples of Indigenous food plants adopted by European newcomers}

In the following sections, we focus on six case examples of Indigenous foods and how they were adopted by European explorers, traders and settlers from the early days of European entry to the continent and through the colonial period.

\section{Matteuccia struthiopteris (L.) Todaro (ostrich fern)}

The only species of fern to have been introduced widely into the North American colonists' diet is Matteuccia struthiopteris 
Tab. 1 Lists examples of some of the medicinal plants that were learned from Indigenous Peoples of North America.

Species

Actaea racemosa L. (black cohosh)

Aralia nudicaulis L. (wild sarsaparilla)

Arctostaphylos uva-ursi (L.) Spreng.

(kinnikinnick, or bearberry)

Asarum caudatum Lindl. (wild ginger)

Coptis trifolia (L.) Salisb. (gold thread)

Echinacea spp. (echinacea)

Juniperus communis L. (common juniper)

Pinus contorta Dougl. ex Loud. (lodgepole pine)

Oplopanax horridus (Smith) Miq. (devil'sclub)

Podophyllum peltatum L. (mayapple)

Polypodium glycyrrhiza D. C. Eaton

(licorice fern)

Populus balsamifera L. (cottonwood,

"balm of gilead")

Prunus serotina Ehrh. (wild cherry)

Rhamnus purshiana D. C. (cascara)

Rubus idaeus L. (wild raspberry)

Sanginaria canadensis L. (bloodroot)

Sassafras albidum (Nutt.) Nees (sassafras)

Thuja occidentalis L. (Eastern white cedar, or arbor vitae)

Ulmus fulva Muhl. (slippery elm)

Viburnum prunifolium L. (blackhaw)
Roots used to treat general illness, kidney ailments, malaria, rheumatism, sore throat and

Reference menstrual irregularities and childbirth.

Leaves used as tonic by First Peoples; used for tea and flavouring and as ingredient in root beer by [34] settlers.

Leaves used for kidney and bladder ailments and as a tonic by First Peoples; widely used similarly $\quad[2,34]$

by settlers and others; still used today in herbal medicine.

Rhizomes and leaves used by Nlaka'pamux (Thompson) and others as medicine and scent; also used by Chinese as a poultice.

Roots used by indigenous peoples; sold in druggist shops in Boston by early 1800s as a medicine for sore eyes and sore mouths.

Roots used by Indigenous Peoples of the Prairies to treat a variety of ailments; widely known as a herbal medicine in North America and beyond.

Fresh berries used by Nlaka'pamux (Thompson) Salish as a bladder medicine and diuretic; used similarly by European settlers; known to Samuel Hearne and other explorers as well.

Pitch from cones and bark used by Nlaka'pamux (Thompson) Salish to treat skin ailments and many conditions; often used by European settlers in the 1920s.

Used widely in W North America to treat ailments such as arthritis, digestive tract disorders, diabetes and many others. Adopted by European settlers in some areas.

Used to treat venereal warts and tumours; used in western medicine as well.

Rhizome used by Northwest Coast First Peoples to treat colds, coughs, sore throats; use learned by European settlers and adopted into the United States Dispensatory list.

Resin widely used as medicinal salve for skin infections, cuts and wounds; a medicine readily adopted by settlers.

Bark used to make medicine for coughs and sore throats; became a well-known settlers' remedy. Bark a well-known traditional remedy for constipation and other digestive ailments by Northwest Coast First Peoples; became known to white settlers in the early 1800s.

Used for women during childbirth, and to treat stomach problems, hemorrhaging, etc. by Indigenous Peoples and settlers alike.

used historically by First Peoples of eastern N America as emetic, respiratory aid, and to treat warts; adopted by settlers and later used commercially in some medicinal preparations.

Used as a medicinal tea, for colds and other ailments by First Peoples, and readily adopted by settlers; later used to flavor "root beer".

Introduced as antiscorbutic medicine to French explorer Jacques Cartier and his men, as

$[100,101]$

described in introduction.

Inner bark used as demulcent for digestive tract ailments by both Indigenous Peoples and settlers; [104] approved for sale by U. S. Food and Drug Administration.

Bark of this and related species used to treat menstrual and cramps, and to prevent miscarriage; widely used herbal medicine to the present day.
(Fig. 9, Fig. 10). It is generally known as the fiddlehead fern or ostrich fern throughout its range, although it is also called the fiddleneck fern in some parts of Maine. In French it is known as the "fougère à l'autruche", with the fiddleheads called either têtes de violon and crosses de fougère, depending on the region. The emerging leaves resemble the end of a violin or fiddle. Today, it is the individual fronds that are harvested and eaten after steaming or boiling, but in the period in which European colonists first arrived, the entire rhizome was also eaten. Plants were removed from the ground, cleaned and pit-cooked [53,54]. This fern is not unique to North America, but is found across the Northern Hemisphere. Although widespread it had only been used sparingly. Records describe its use as a vermifuge in Russia, as goat feed and a beer flavouring agent in Norway. In comparison, the Malecite, Penobscot and Pasmaquoddy Indians of New Brunswick and Maine included it as an important part of their diet. The Malecite Indians of
New Brunswick call it mahsos, which refers to the circling movement a dog makes as it lies down. Mahsos also has connotations of magic [55].

The culinary popularity of this fern dates to 1783 . As the American War of Independence came to a close, many Americans loyal to the British crown (known as United Empire Loyalists) left New York and Boston for New Brunswick, Canada. The supplies of these refugees proved inadequate and by spring they were starving. The local Malecite Indians showed the displaced Americans how to prepare this fern [56]. In the springtime, the Malecites cooked the emergent leaves in animal fat and ate them not only as a food, but as a medicine, since, they, too were aware that crosiers of a number of different fern species were good vermifuges. Fiddleheads became a culinary tradition among settlers in the St. John River valley. The fern's popularity spread during the 19th century to other Canadians in the Maritime 
Tab. 2 Key examples of Indigenous food plants and fungi of North American First Peoples, adopted by European and other newcomers to the continent.

\section{Algae}

Porphyra spp. and Pyropia spp (red laver);

Bangiaceae

Palmaria palmata (L.) Kuntze (dulse);

Palmariaceae

\section{Lichens}

Bryoria fremontii (Tuck.) Brodo \& Hawksw.

(black tree lichen, wíla); Parmeliaceae

Actinogyra spp., Umbilicaria spp., including

some formerly classed as Gyrophora spp. (rock

tripe, tripe de roche); Gyrophoraceae

\section{Fungi}

Tricholoma magnivelare (Peck) Redhead

(pine mushroom, American matsutake);

Tricholomataceae

\section{Ferns}

Matteuccia struthiopteris (L.) Todaro (ostrich, or fiddlehead fern); Dryopteridaceae

\section{Coniferous trees and shrubs}

Juniperus communis L. (common juniper);

Cupressaceae

Picea mariana (Mill.) Britton, Sterns \&

Poggenb.; (black spruce) and other Picea spp.

(spruces); Pinaceae

Pinus edulis Engelm. and other Pinus species

with large, edible seeds (pinyon pine); Pinaceae

Flowering plants, including trees, shrubs, herbs

Acer saccharum Marsh. and other Acer spp.

(sugar maple); Aceraceae)

Agave americana L. and Agave spp. (agave, century plant); Agavaceae

Allium cernuum Roth (nodding onion) and other Allium spp. (wild onions); Liliaceae

Allium schoenoprasum var. sibiricum (L.)

Hartm. (wild chives); Liliaceae

Allium tricoccum Blanco (wild leek); Liliaceae

Amelanchier alnifolia (Nutt.) Nutt. ex M. Roem. (saskatoonberry); Rosaceae
Dried and eaten in a variety of dishes; especially valued by Chinese and Japanese immigrants to the west coast of North America.

Eaten by Indigenous Peoples of the Atlantic coast, but more commonly by

Europeans, who quickly adopted its use in the Maritimes of North America.

Harvested from coniferous tree branches at upper elevations, leached in water and

$[33,107,108]$ pit-cooked, often with onions or camas bulbs, by Indigenous Peoples of western North America; adopted as an emergency food by explorers and settlers. Known to Cree, Chipewyan, Inuit and other Indigenous Peoples as a "fall back" in times of famine; used as emergency and famine food by explorers, voyageurs and French Canadian Jesuit Fathers.

Eaten by Nlaka'pamux and some other Interior Salish peoples; widely sought by Japanese immigrants, and now harvested on a commercial scale in western North America.

Nearly \$24000 worth imported into US from Canada as of 1980; annual harvest NB of 200 tons $-4 \times$ that of Maine; marketed frozen, fresh and canned.

$[3,33,51]$ (see case study in text)

Berries eaten occasionally by Indigenous Peoples, mostly for medicinal purposes; use adopted readily by Scandinavians and other Europeans to flavor sauerkraut, gin and $[8,19,31-33$, other drinks; early explorers like Samuel Hearne (in the late 1700s) infused berries in brandy for cordial.

Use of spruce beer probably originated from spruce needle tea drunk as a health beverage by Indigenous Peoples; adopted by European explorers like James Cook as an antiscorbutic (using other conifer species).

Seeds harvested from wild in American Southwest especially by Navaho and other

Native Americans and eaten raw or toasted; widely adopted by settlers and still marketed today.

Sap harvested and rendered into a sweet syrup, as well as crystalline sugar by First Peoples of eastern North American hardwood forests; widely adopted by settlers, and (see case study in widely marketed today; average annual value of syrup and sugar nearly \$14 million as text) of 1980 in US, with $\$ 9$ million worth of imports from Canada, mostly Quebec. Leaf bases and rootstocks of several species pit-cooked and eaten in Arizona and elsewhere in southwestern United States, as well as Mexico; used to make fermented drinks, tequila and mescal; adopted by Spanish explorers and settlers and these drinks are widely marketed today, mostly from Mexico.

Widely harvest by Indigenous Peoples in the Interior Plateau and Great Basin of western North America; pit-cooked bulbs very sweet due to fructose from inulin; eaten by explorers like Simon Fraser and Captain James Cook and their crews, as well as by settlers throughout the region; nodding onion is a featured Slow Food Product of Canada.

Eaten raw or cooked by northern Indigenous Peoples; also used by Alexander Mackenzie and other explorers, as well as settlers of the north.

Bulbs reportedly eaten by the Iroquois, Potawatomi and Cree, Anishenaabe and others, used raw with meat, cooked in soups, or boiled and seasoned with oil; adopted by settlers in Quebec and elsewhere.

Sweet juicy fruits widely eaten fresh or dried in cakes, or as pemmican by Indigenous Peoples of Central and Western North America; widely adopted by explorers, traders and settlers; still used today; for syrup, jam, jelly, pies; recent cultivars developed; Saskatoon berries are a featured Slow Food Product of Canada.
$[3,6,9,13,31-33$, $41,110,116,117]$ (see case study in text, and Tab. 3) 
Amphicarpa bracteata (L.) Fern. (ground-bean, hog-peanut); Fabaceae

Angelica lucida L. (seacoast angelica, or seawatch, or "wild celery"); Apiaceae

Apios americana Medic. (groundnut); Fabaceae

Argentina egedii (Wormsk.) Rydb. - syn. Potentilla egedii Wormsk., and Argentina anserina (L.) Rydb. - syn. Potentilla anserina L. (silverweed, or cinquefoil); Rosaceae Asclepias syriaca L. (common milkweed); Asclepiadaceae

Asimina triloba (L.) Dunal (pawpaw);

Annonaceae

Camassia quamash (Pursh) Greene (common camas) and Camassia leichtlinii (Baker) S.

Watson (great camas); Liliaceae

Carya illinoiensis (Wagenh.) K. Koch (pecan); Juglandaceae

Carya ovata (Mill.) K. Koch (shagbark hickory) and other spp.; Juglandaceae

Castanea dentata (Marsh.) Borkh. (sweet chestnut); Fagaceae

Ceanothus americanus L. (New Jersey tea); Rhamnaceae

Cirsium brevistylum Cronquist (clustered thistle) and C. edule Nutt. (edible thistle) and other Cirsium spp.; Asteraceae Claytonia lanceolata Pall. ex Pursh (spring beauty, or "mountain potato") and other tuberous Claytonia spp., Portulacaceae Clinopodium douglasii (Benth.) Kuntze - syn. Satureja douglasii (Benth.) Briq. (Yerba Buena); Lamiaceae

Cochlearia officinalis L. (scurvy-grass); Brassicaceae

Corylus americana Walter (American hazelnut), Corylus cornuta Marsh. (beaked hazelnut); Betulaceae

Empetrum nigrum L. (crowberry); Empetraceae

Epilobium angustifolium L. (fireweed); Onagraceae

Fagus grandifolia Ehrh. (American beechnut); Fagaceae

Fragaria chiloensis (L.) Mill., F. vesca L. and $F$. virginiana Duchesne (blueleaf, wild strawberries); Rosaceae

Fritillaria affinis (Schult.) Sealy (chocolate lily) and Fritillaria camschatcensis (L.) Ker Gawl. (northern riceroot); Liliaceae
Seeds eaten raw or boiled by various eastern Indigenous groups, including

$[3,18,33$, Anishenaabe and other Great Lakes peoples; adopted by English colonists. $112,118,119]$ Leaves and peeled stalks were, and still are, a favorite food of some Indigenous Peoples of Alaska and northern coasts of Canada; adopted by European explorers and settlers.

Large, excellent flavored tubers eaten raw, cooked, or made into flour by eastern Indigenous Peoples; occasionally eaten by settlers.

Fleshy roots as food by Indigenous Peoples of western North America; occasionally eaten by explorers and settlers.

$[3,18,30,33,112]$

Young shoots, flowers, young pods, cooked and eaten as a green by settlers, possibly

$[3,5,30,112,115]$ learned from Indigenous Peoples of eastern North America.

Ripe fruits eaten by Indigenous Peoples of eastern hardwood forests; adopted by explorers and settlers; marketed in season.

Bulbs one of the most important "root" foods of western North American

Indigenous Peoples, from southwestern British Columbia to Montana

and south to California; adopted by explorers like Lewis and Clark, and used by settlers in western United States; pit-cooked bulbs very sweet due to fructose from inulin.

Nuts eaten by First Peoples of the midwestern and southern United States; now a major wild and plantation crop; Worth \$22 million/year as of 1980 .

$[3,51]$ (see case study in text)

$[3,9,19,30,33,35$,

Nuts of various spp. an important food for Indigenous Peoples of eastern North

America; early European explorers and entrepreneurs enjoyed hickory nut foods and oils, and described groves near Indian villages where nut trees were managed in an orchard-like fashion.

Nutritious nuts widely enjoyed, cooked and stored by Native Americans of the eastern hardwood forests; adopted by explorers, traders and settlers; now virtually extinct because of chestnut blight introduced from Asia.

New Jersey tea drunk as a beverage and medicinal tea by Native Americans of eastern $\quad[3,8,9]$ North America; adopted by settlers; long known as a folk medicine.

Roots and young stems cooked and eaten by some Indigenous Peoples of western North America; Lewis and Clark and other explorers ate the roots, as did some settlers; pit-cooked roots very sweet due to fructose from inulin.

Succulent corms, steamed, were a staple carbohydrate source for Indigenous Peoples of western North America; other species eaten in east; readily adopted by explorers and settlers.

Used for beverage tea by Indigenous Peoples of west coast of North America; adopted $[8,32,33]$

as a tea by Spanish settlers, Hudson's Bay voyageurs and trappers and early pioneers.

Succulent leaves eaten as a green by Inuit and by early explorers, prospectors, traders.

$[7,28,92]$

Nuts were a staple of Indigenous Peoples throughout the range of these plants; quickly adopted by explorers, traders and settlers, until generally replaced by European filberts.

$[3,9,31-33]$ (see case study on nuts in text and Tab. 3) $[9,31-33$, $91,92,110]$ European explorers, traders and settlers; juice used for beverage and fermented for wine.

Young shoots eaten as a springtime green by First Nations of western Canada; French $\quad[8,19,32-34,109]$ Canadian voyageurs made a potherb from this plant, called l'herbe frette.

Nuts eaten by Indigenous Peoples of the eastern North American hardwoods; used

$[3,7-9,30,33,62]$ by settlers; formerly harvested and sold in markets in Canada and United States.

Sweet, flavorful berries eaten fresh and dried by Indigenous Peoples throughout their $[3,9,19,26,31-33$, range; readily adopted by European newcomers for making jam, jelly and to eat fresh; 40,41,110] (see sometimes sold to white settlers.

Bulbs eaten by First Peoples of western North America and sometimes harvested by

(see case study in

$[3,8,9,121]$ (see

case study in text)

$[16,29,31,33,115]$

explorers and settlers, but known for having a bitter taste. 
Gaultheria hispidula (L.) Muhl. Ex Bigelow (creeping snowberry); Ericaceae Gaultheria procumbens L. (wintergreen, "teaberry"); Ericaceae

Gaultheria shallon Pursh (salal); Ericaceae

Hedysarum alpinum L. (licorice root, "Indian potato"); Fabaceae

Helianthus tuberosus L. (Jerusalem artichoke); Asteraceae

Heracleum maximum Bartram (common cowparsnip, "Indian celery," or "Indian rhubarb"); Apiaceae

Ilex vomitoria (Sharp) E. Murray (yaupon tea, "cassina" or "black drink"); Aquifoliaceae

Juglans nigra L. (black walnut) and J. cinerea $\mathrm{L}$. (butternut) and other Juglans spp.; Juglandaceae

Lewisia rediviva Pursh (bitterroot); Portulaceae

Lomatium cous (S. Watson) J. M. Coult. \& Rose (cous, biscuitroot) and other Lomatium spp.; Apiaceae

Mahonia aquifolium (Pursh) Nutt. (tall Oregongrape) and M. nervosa (Pursh) Nutt. (dullleaved Oregon-grape); Berberidaceae Maianthemum racemosum (L.) Link (false Solomon's seal, or false spikenard); Liliaceae

Malus fusca (Raf.) C. K. Schneid. (Pacific crabapple); Rosaceae

Mentha arvensis L. (field mint, or Canada mint); Lamiaceae

Monarda fistulosa L. (wild bergamot, beebalm); Lamiaceae

Montia perfoliata (Donn) Howell (miner's lettuce); Portulacaceae

Morus rubra L. (red mulberry); Moraceae

Oemleria cerasiformis (Torr. \& Gray ex Hook. \& Arn.) Landon (Indian plum or bird cherry); Rosaceae)

Opuntia spp. (prickly-pear cactus); Cactaceae

Oxyria digyna (L.) Hill (mountain sorrel); Polygonaceae
Berries eaten by Indigenous Peoples throughout their range; popular among the early $[9,31,33]$ settlers of eastern Canada and the US; sometimes gathered and sold in local markets. Berries eaten by Indigenous Peoples throughout their range; popular among early settlers of eastern Canada and the United States; sometimes sold in local markets, and used for flavouring tea and chewing gum; original source of oil of wintergreen. Berries among the most important fruits of Indigenous Peoples of western North America; picked in immense quantities and dried for winter; adopted by explorers and settlers, and used for jam and jelly up to the present day. Roots eaten by northern Indigenous Peoples; known to and used by explorers such as John Richardson and Alexander Mackenzie [who recognized that the related Hedysarum boreale Nutt. ssp. mackenzii (Richards.) Welsh is highly toxic].

Sunflower relative originating in Missouri Valley, where it was semi-cultivated for its edible tubers, which were widely used by Indigenous Peoples; adopted by settlers of eastern North America and still grown and marketed today; well cooked roots very sweet due to fructose from inulin.

Widely used green by Indigenous Peoples of North America, especially in the west; known to eastern Europeans as an edible green; eaten by explorers like Alexander Mackenzie, and sometimes by settlers.

A tree, a relative of holly, native to southeastern North America from Maryland to Florida and used as a medicinal and beverage tea by Native Americans of the region; adopted as a drink by explorers and settlers.

Nuts of these species were staple foods of First Peoples throughout their range;

readily adopted by explorers like Samuel de Champlain, and by traders and settlers; still used today, but largely replaced by European walnuts.

Starchy taproots eaten by Indigenous Peoples of the Interior Plateau and Great Basin of North America; although somewhat bitter in taste they were eaten by Lewis and Clark and other explorers, and occasionally by settlers.

Starchy taproots and tuberous roots were a staple food of Indigenous Peoples of western North America; were adopted by explorers and settlers, especially as emergency food.

Tart berries eaten by Indigenous Peoples of western North America, usually along with other berries; used by settlers for jam, jelly or wine.

Young greens, fleshy rhizomes, and ripe berries of this plant all eaten occasionally by Indigenous Peoples in various parts of Canada; Russian immigrants harvested the young green shoots as "sas-a-qui", but many other settlers considered them to be poisonous. Occasionally people have been poisoned by confusing the shoots with those of Veratrum, false hellebore, which is highly toxic.

Fruits have been a staple food for Indigenous Peoples of western North America; adopted by some explorers, traders and settlers, but usually only for sweetening, for making jelly.

Leaves and stems used to make a medicinal and beverage tea by First Peoples across its range; adopted as a beverage plant by newcomer travellers and settlers.

Leaves used for tea by some Indigenous Peoples in the Interior Plateau of North

America, and adopted as a tea by European traders and settlers.

Fresh young leaves eaten by Indigenous Peoples in western North America; adopted as a salad green by European prospectors, miners and settlers; this is a featured Slow Food Product of Canada.

Berries eaten by Indigenous Peoples of central and eastern North America; readily adopted by European explorers and settlers.

Small plums eaten by Indigenous Peoples of western North America; occasionally eaten fresh by children of settlers, in the past; rarely eaten today.

Fleshy pads and fruits eaten by Indigenous Peoples of western North America, especially the Southwest; used by Spanish and other European explorers as emergency food and by settlers for greens and preserves.

Green leaves eaten by northern Indigenous Peoples; also by explorers as an antiscorbutic.

$[9,32,33,41]$

$[28,33,34,110]$

$[3,33,124]$ (see

Tab. 3)

$[7,19,31-33,110]$

$[16,31,33]$

$[9,31-33,41]$

$[9,32,33,41]$ (see

Tab. 3)

$[8,31-33,110]$ 
Nelumbo lutea (Willd.) Pers. (American lotus, or water-chinquapin); Nymphaeaceae

Perideridia gairdneri (Hook. \& Arn.) Mathias (wild caraway, or yampah); Apiaceae Physalis heterophylla Nees (ground cherry, husk tomato) and related spp.; Solanaceae Phytolacca americana L. (pokeweed); Phytolaccaceae

Podophyllum peltatum L. (mayapple); Podophyllaceae

Prunus americana Marsh., P. angustifolia Marsh., P. nigra Aiton and related species (wild plums); Rosaceae

Prunus pensylvanica L. f. (pin cherry); Rosaceae

Prunus virginiana L. (choke cherry); Rosaceae

Quercus spp. (oaks); Fagaceae

Rhododendron groenlandicum (Oeder) K. A.

Kron \& W. S. Judd - syn. Ledum groenlandicum Oeder (Labrador-tea) and R. neoglandulosum Harmaja - syn. L. glandulosum Nutt. (trapper's tea); Ericaceae

Ribes divaricatum Douglas, Ribes

oxyacanthoides L. and other Ribes spp. (wild

gooseberries); Grossulariaceae

Ribes hudsonianum Richardson, Ribes triste

Pall. and related spp. (black and red currants); Grossulariaceae

Rubus chamaemorus L. (cloudberry, or bakeapple); Rosaceae

Rubus idaeus L. (wild raspberry); Rosaceae

Rubus leucodermis Douglas ex Torr. \& A. Gray (blackcap) and R. occidentalis L. (black raspberry); Rosaceae

Rubus parviflorus Nutt. (thimbleberry); Rosaceae

Rubus spectabilis Pursh (salmonberry); Rosaceae

Rubus ursinus Cham. \& Schltdl., Rubus allegheniensis Porter and related spp. (wild blackberries); Rosaceae

Sagittaria latifolia Willd. (wapato, or broadleaf arrowhead), and S. cuneata Sheldon (arumleaf arrowhead); Alismataceae
Dried rhizomes cooked with venison, corn, beans by Anishenaabe and Potawatomi, and the roasted seeds were also eaten; explorers and settlers ate the seeds and cooked greens on occasion.

Carrot-like rhizomes eaten, cooked, throughout their range by Indigenous Peoples, and also sought by explorers and settlers.

Ripe fruits eaten by Iroquois and Plains Indigenous Peoples; and also eaten by explorers and settlers.

Young shoots cooked and eaten by Iroquois and Malecite peoples, as well as by settlers (but now considered toxic due to mitogens).

Fully ripe fruits eaten fresh or dried by the Iroquois and Anishenaabe of the Great Lakes region as well as Indigenous Peoples to the south; also eaten by Samuel de Champlain and other explorers and baked in pies by settlers; greens, roots and unripe fruits are toxic.

Ripe fruits of these species eaten fresh or preserved by Indigenous Peoples

$[4,29,31-33]$

$[3,6,30,33,42]($ see

Tab. 3)

$[3,30,33,127]$

$[3,9,19,30,33$,

throughout their range; Prunus nigra cultivated by Mi'kmaq; wild plums widely used by early explorers and settlers, and are the predecessor of several cultivated plum varieties.

Small and tart, were widely used by North American Indigenous Peoples, as well as by early explorers and settlers, who usually made them into jelly.

Fruits astringent before fully ripe, but after frost become flavourful; widely eaten by Indigenous Peoples throughout the range, as well as by early explorers and settlers, usually in the form of juice or jelly.

Acorns of many different oak species, especially the white oak group, eaten by

$[3,6,9,30,32,33$, Indigenous Peoples across North America; usually need to be leached and processed; 121] (see case eaten occasionally as a famine food by European explorers and settlers.

Fragrant leaves (and flowers) used to make a tea by Indigenous Peoples across study on nuts in text)

$[8,19,31-33,40$, northern North America; readily adopted by fur traders as a beverage, and widely used by settlers; possibly introduced as a beverage to western Indigenous Peoples by the fur traders.

Ripe gooseberries eaten throughout their range by Indigenous Peoples; also eaten by explorers and settlers, fresh or in the form of sauce, pies and tarts.

$[9,30-33$, $41,110,112,128]$ (see Tab. 3)

Red and black currants eaten by Indigenous Peoples across North America; also enjoyed by explorers, traders and settlers .

Ripe berries eaten by Indigenous Peoples across North America, as well as by

European explorers and immigrants; known to Scandinavians and other Europeans from northern Europe.

Ripe berries eaten by Indigenous Peoples across North America, and relished by European explorers and settlers, who were familiar with them from Europe. Berries eaten throughout their range, fresh or dried, by Indigenous Peoples and also readily adopted by settlers, who ate them fresh or canned for winter, or in the form of jam or jelly.

Berries and young shoots, peeled, eaten by Indigenous Peoples of western North America; eaten fresh and as jam or jelly by European explorers, traders and settlers, especially children, who also sometimes peeled and ate the shoots.

Fresh berries and young peeled shoots eaten by Indigenous Peoples of western North America; seldom dried; European traders and settlers ate them fresh from the bushes and, with sugar as a dessert.

Sweet, flavourful berries eaten fresh and dried by Indigenous Peoples throughout their range; also enjoyed by European travellers and settlers, fresh, canned, or made into jam and jelly; later sold in markets as a "cash" crop; recently largely taken over by introduced blackberries: Himalayan (Rubus armeniacus Focke) and cutleaf (Rubus laciniatus Willd.).

Tubers eaten throughout their range by Indigenous people of North America. Eaten by explorers such as Lewis and Clark, and later widely sought by Chinese immigrants who were familiar with them from Asian species.
$[9,31-33,41]$

[9,31-33,41]

$[9,32,33,41]$

[9,31-33,41] (see Tab. 3)
$[3,7,16,32,33]$ 
Sambucus nigra L. [including ssp. cerulea (Raf.) R. Bolli; black elder, blue elderberry]; Caprifoliaceae

Sassafras albidum (Nutt.) Nees (sassafras); Lauraceae

Typha latifolia L. (cattail, bulrush); Typhaceae

Vaccinium alaskaense Howell (Alaska blueberry), Vaccinium ovalifolium Sm. (ovalleaved blueberry); Ericaceae Vaccinium membranaceum Douglas ex Torr. (black mountain huckleberry); Ericaceae

Vaccinium angustifolium Aiton, V. corymobsum L. (wild blueberries); Ericaceae

Vaccinium myrtilloides Michx. (velvetleaf blueberry, or Canada blueberry), V. uliginosum L. (bog blueberry); Ericaceae Vaccinium ovatum Pursh (evergreen huckleberry); Ericaceae

Vaccinium macrocarpon Ait., V. oxycoccos L. syn. Oxycoccus (bog cranberry, or small cranberry); Ericaceae

Vaccinium vitis-idaea L. (lingonberry, or lowbush cranberry); Ericaceae

Vaccinium parvifolium Sm. (red huckleberry); Ericaceae

Viburnum edule (Michx.) Raf. (highbush cranberry, or squashberry) and V. opulus $\mathrm{L}$. (American highbush cranberry); Caprifoliaceae

Zizania aquatica L. and related spp. (wild-rice); Poaceae
Berries eaten by Indigenous Peoples throughout their range, often mixed with other berries and cooked; Settlers substituted them for grapes in making jelly, and left the bushes in their fields when they cleared for agriculture; occasionally made wine from berries and flowers.

Root bark and leaves used by Anishenaabe, Iroquois and other Indigenous Peoples of eastern North America for a beverage tea and to season cooking meat and other foods; first discovered by Europeans in 16th century, during Spanish explorations of Florida and mistaken for cinnamon; bark imported to Europe as a medicine; adopted as a tea by settlers throughout its range and used to flavor root beer.

Rhizomes roasted and eaten in early spring by some Indigenous Peoples of western and northern North America; young shoots also sometimes eaten; known to Cossacks of Russia as a green vegetable, and shoots eaten occasionally by European travelers and settlers.

Berries eaten fresh or dried into cakes for winter by Indigenous Peoples of western North America; readily adopted by Europeans, and used by settlers for jam, pies and desserts.

Berries were a favourite throughout their range and eaten by all Indigenous groups; maintained by burning and tending; eaten by European explorers, traders and settlers and widely marketed; today often displaced by cultivated blueberries but still a major non-timber forest product.

Berries widely eaten by Indigenous Peoples of eastern North America; readily adopted by European newcomers, including Samuel de Champlain, used for pemmican, jams and desserts; formed the basis of a major industry, still important today.

Berries of these species widely eaten throughout their range by Indigenous Peoples of North America; picked and bought from First Peoples by explorers like Alexander Mackenzie, who paid with "beads, awls, knives and tin".

Berries, which ripen in mid-late fall, and sometimes into winter, eaten by Indigenous Peoples of the Northwest Coast of North America, and also readily adopted by settlers, who called them "shot huckleberries" because of their small, clustered nature. Tart berries, ripening in fall, were stored under water or fresh over the winter and eaten throughout their range by Indigenous Peoples, often with oil or grease; eaten by the pilgrims and other settlers, and marketed by fur traders; many varieties bred; known especially as a sauce for poultry and meat.

Small clustered berries ripen in fall, widely eaten by Indigenous Peoples across northern North America, as well as throughout northern Europe; readily adopted by explorers, traders and settlers in the New World; still marketed.

Berries eaten by Indigenous Peoples of western North America, fresh or dried in cakes; berries eaten by explorers, and used by European settlers for jelly, jam and pies.

Tart fruits ripen in fall; widely eaten by Indigenous Peoples of North America; also known to Europeans and readily adopted by explorers and settlers, who used them for syrup and liqueurs; Maine lumbermen ate them with molasses; French Canadian voyageurs called them Pembina berries.

Staple food of Indigenous Peoples of eastern and central North America for countless generations; widely adopted by explorers, traders and settlers; still commonly harvested and marketed today; a featured Slow Food Product of United States.
$[3,6,7,9,31-33,41]$

$[3,8,30,33]$

$[6,7,31,33]$

$[9,29,31-33]$

$[9,29,31-33,41]$

$[3,6,9,19,33,51]$

(see Tab. 3)

$[6,9,31-34,40,110$ 129]

$[9,32,33]$

$[3,6,9,19,31-34,51]$ (see case study in text, and Tab. 3)

$[6,9,19,31-33$

$[9,32,33,41]$

$[3,6,9,31-33,110]$

$[3,9,13,33,51,66]$ (see case study in text)
Provinces and Americans in New England. It continues to spread. Fiddleheads gathered in the British Columbia Interior are available in the spring in Vancouver and Victoria. The founders of companies selling fresh fiddleheads are almost exclusively displaced Maritimers. Market opportunities have generally increased in the last 30 years as local enthusiasts in other parts of Canada and New England harvest these ferns every spring. This has resulted in widespread availability of fiddleheads in restaurants and food retail outlets. Freezing techniques and air shipping have made them a specialty food available worldwide.

Currently, the demand for the fiddleheads outstrips supply, which is entirely from the wild. By the early 1980s, the annual commercial harvest of "fiddlesticks", obtained almost entirely from the wild, was estimated at $225000 \mathrm{~kg}$. Nearly $\$ 24000$ worth were imported into the United States from Canada as of 1980. The annual harvest in New Brunswick was four times that of Maine [51]. Although there have been occasional 
attempts to cultivate the fern, these have largely failed. The fern grows well in shaded river floodplains, but needs constant irrigation and shade if it is to grow well in fields. Furthermore, it requires many years before it can produce a crop of large leaves $[19,33,54,55]$.

There are a variety of ways to prepare fiddleheads. They can be steamed or boiled and served with butter and lemon juice. Boiled fiddleheads can be left to cool and then made into a salad, either as a prime or a supplementary ingredient. Alternatively, they can be fried in bacon fat, which according to Malecites is the best way to eat them. Unlike many other ferns, such as bracken, fiddleheads are not known to be carcinogenic.

\section{Zizania spp. (wild-rice)}

Of all of the Indigenous foods adopted and used by the early fur traders in eastern North America, Wild-rice was probably the most important. Three North American species of wild-rice are recognized by the USDA plant database [57]: annual wildrice ( $Z$. aquatica L.) northern wild-rice (Z. palustris L.) and Texas wild-rice ( $Z$. texana Hitchc.), the last is endangered and restricted to Texas. A fourth species, Zizania latifolia (Griseb.) Turcz. ex Stapf, grows in Manchuria [58]. The most common wild-rice species, $Z$. aquatica, grows in wetlands, along quiet channels, ponds, and lake edges of the Great Lakes district of eastern North America, where many First Peoples cultivate it. Some sow it by hand, whereas others let it seed itself naturally. Ducks and other wildlife also depend on wild-rice.

The Anishenaabe (Ojibwa, or Chippewa) are perhaps the best known for their use of wild-rice, and one group, the Menominee, are named after wild-rice, called "menomen" in the Anishenaabe language. People usually harvested the grains from canoes (some still do), with one harvester bending the rice-laden stalks over the canoe and another threshing or beating them so that the grains drop off into the canoe. The grains are parched and stored, formerly in bark boxes or woven sacks. They are served boiled or cooked in soup. Harvesting and preparation of wild-rice are described in detail in many sources [59-65].

Jenks [65] cites numerous accounts of how the First Peoples provisioned explorers and fur traders with this valuable commodity. In July 1775, near Grand Portage, Minnesota, Explorer Alexander Henry bought fish and wild-rice, which, he noted, the local First Peoples had in great abundance. At Lake of the Woods, Ontario, he was given 100 bags of wild-rice of nearly one bushel each. He declared that, without large quantities of wild-rice, the voyage beyond the Saskatchewan river could not have been completed. Again, at Lake Winnipegon, or Winnipeg (Winipec), the Indians gave him "the usual presents of wild-rice and dried meat" [65]. In 1766, American explorer and writer Jonathan Carver wrote [65]: "In future periods [wild-rice] will be of great fervice to the infant colonies, as it will afford them a prefent fupport, until in the courfe of cultivation other fupplies may be produced".

Geographer Dr. Jedidiah Morse noted in 1822 [65]: “The fish and the wild-rice are the chief sustenance of the traders, and without them the trade could scarcely be carried on". In fact, on many occasions, wild-rice and the First Peoples who provided it saved the lives of traders and settlers. An inducement for settling at Weed Lake (Lake Schabeechevan) was said to be because of the "plentiful supply of fish, rice, and cranberries, which are winter comforts of too great consequence to be slighted" [65]. The rice was often accompanied by other foods such as dried meats, bear grease and beaver skins. The

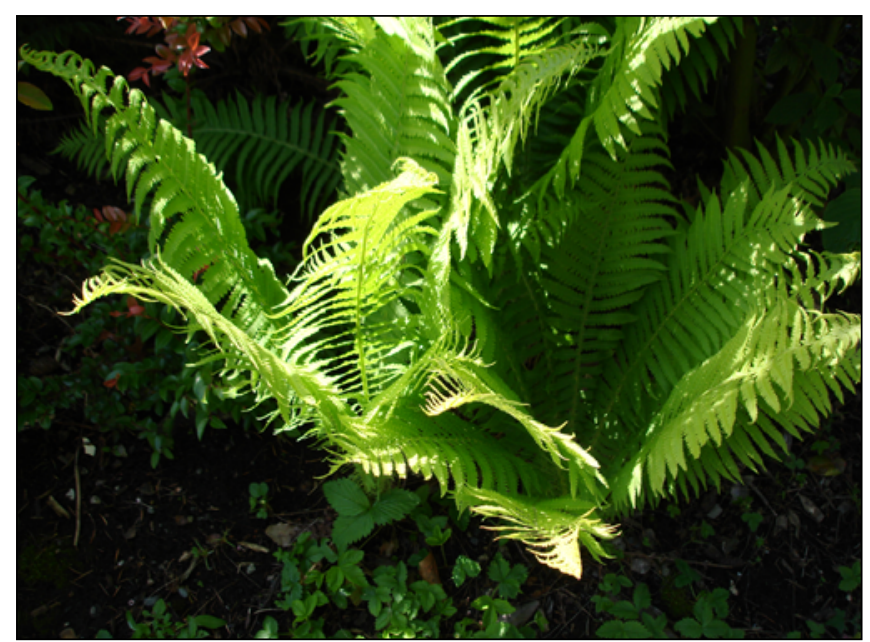

Fig. 9 Ostrich fern (Matteuccia struthiopteris).

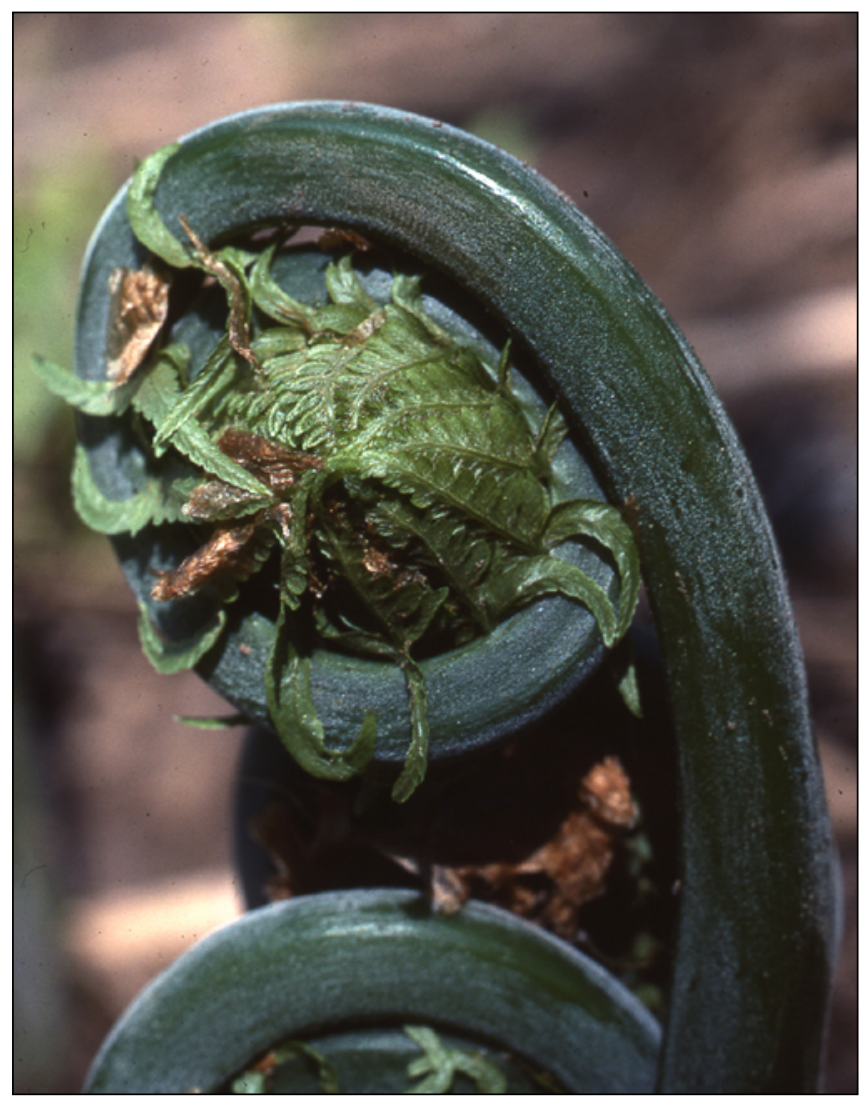

Fig. 10 Ostrich fern fiddleheads.

Northwest Company's fort and Fur Post at Leech Lake, Minnesota was described in 1805 as having "chests with 500 bushels of wild rice". The following year, the Company's station at Lake de Sable (Sandy lake), Minnesota, was described as having many provisions (potatoes, caught fish, and game), "but the provision they chiefly depend upon is wild oats [wild-rice], of which they purchase great quantities from the savages [sic], giving a the rate of about one dollar and a half per bushel" [65].

Later, the use of the "interesting and valuable grain" by whites seems to have declined, as noted in a letter by J. A. Gilfillan in May 1896, from White Earth, Minnesota [65]: "Among whites in Minnesota (near White Earth) it is used only by missionaries and their families, old Indian traders, and 
very old settlers, and by a few merchants along the line of the St Paul Railroad". Nevertheless, wild-rice was offered for sale in 1896 in several towns in Wisconsin and Minnesota and was also sold at various Indian Reservations and in towns in their vicinity. It was shipped quite extensively, usually 1-2 tons per season, from Chetek to Menomonie, Chippewa Falls and other places. Some people were very fond of it, and some white settlers preferred it to the common rice of the south [65]. It was also often sold at gun clubs, since people planted it in small lakes as food for waterfowl. It is said to have been traded, at least in historic times, by the Nlaka'pamux of British Columbia at Banff and Calgary from the Cree and other eastern groups [29], and there is apparently a substantial wild-rice population in the Fraser Valley of British Columbia (Abe Lloyd, personal communication, 2009).

Within recent decades, wild-rice has been a valued local commodity, bringing as of 1980, for example, an average annual value in the United States of over $\$ 4$ million as of 1980; with about $\$ 2$ million worth of wild-rice imported from Canada [51]. Wild-rice has been suggested as a potential crop plant for the Florida Everglades, among other regions of North America [66]. In the late 1970s, commercial production of wild-rice began in the Sacramento Valley of California. In 1986, California's 15 thousand acres of wild-rice paddies yielded more than 10 million pounds ( 4.5 million $\mathrm{kg}$ ) of wildrice, estimated to be about 20 times the quantity of wild-rice harvested from natural habitats in its native range. Hence, the future of wild-rice production marketing by Indigenous Peoples is somewhat bleak [67].

The legacy of wild-rice and its importance is reflected in the countless place names that commemorate it: Rice Lake, Rice River, Rice Swamp, Rice Marsh, le Pays de la Folle Avoine (for the territory to the south of Lake Superior along the west side of Lake Michigan), and Menomin County, Menomonee township, Minnesota.

\section{Acer saccharum (sugar maple) and related species: maple syrup}

Maple trees - especially Acer saccharum, sugar maple, but also other Acer species - in the spring produce a sap that is sweet. Early French records note that maple water tapped directly from trees was drunk by First Nations peoples [68]. Maple sap is a solution of sugar (mostly sucrose) plus small amounts of proteins, lime, and potash in water. Seventeenth century records mention that boiling it down to a third of its original volume resulted in a syrup. Freezing this syrup brought about crystallization, creating maple sugar. Maple sugar was used widely in eastern North America to season meats, fruits and vegetables. Since salt was not used by First Nations at the time of colonization, many observers noted that maple sugar was used in seasoning where colonists would have used salt. It was also used in children's medicines, since medicine boiled in syrup was easier to ingest [49]. Maple sap was exploited long before colonists arrived. Maple trees and sugaring figure in a variety of Native American myths [69].

First Nations known to have harvested maple sap for making syrup and sugar include: Iroquois, Anishenaabe (Ojibwe), Potawatomi, Mi'kmaq, Malecite, Naskapi, Montagnais and Algonquin [33]. From all accounts it is clear that colonists were quick to learn from the First Nations. This has grown into a large industry in eastern North America, producing over 30 million litres annually. Maple sugar is emblematic of Québec, the Canadian province that produces nearly three-quarters of the world's maple syrup.
Maple syrup is generally made from sugar maple (Acer saccharum), because this species has the greatest flow and is particularly rich in sugar. The flow of sap is caused by the diurnal alteration of freezing and thawing temperatures, which cause pressure to decrease and increase respectively in the sapwood. By either deeply scoring the bark, as First Nations people did, or by drilling a hole into the wood as colonists did, sap would flow copiously into pails during the day. Although other maples, e.g. Acer negundo, have been used both by natives and colonists, most do not have sufficiently high sugar content or sap flow to warrant the labour of harvesting and processing.

Corylus spp. (hazelnuts), Carya spp. (hickories), Juglans spp. (walnuts and butternut), Quercus spp. (oak acorns) and others (nuts)

Nuts from various trees and shrubs formed a regular part of the diet of many North American First Nations. Many were taken up by settlers, but others were seldom adopted, except out of necessity. An example of a particular form of dietary dependence on nuts was balanoculture, the harvesting and processing of acorns from oaks (Quercus spp. and related species). Known from prehistoric hunter-gatherer societies throughout the world wherever oaks grew in abundance, during precontact times in North America balanoculture was practiced most intensively in California [70]. Settlers did not like the bitter taste of Garry oak, or Oregon white oak (Quercus garryana) or of most other acorns. Instead, those nut species that were related to those used in Europe were most likely to be adopted. The American black walnut, which was prized by many, but in particular in Apache cuisine [71], was easily accepted by European colonists because of its resemblance in taste to walnut species with which they were already familiar. Captain John Smith, founder of the Virginia colony, commented that local natives having planted their fields in May and June then lived mostly off acorns, walnuts and fish [49]. Other nuts that became popular with settlers included hazelnuts, chestnuts, hickories, butternuts and pecans. Chestnuts (Castanea dentata) formed the base of the culture of settlers who moved into the Appalachians. Chestnuts were used for human food and cattle feed until the tree went was wiped out by a blight fungus introduced from Asia and became nearly extinct early in the last century. This destroyed what has been described as way of life in which the chestnut was the key species [72]. Nut tree sap, such as that of shagbark hickory (Carya ovata), was processed like maple syrup; it was not used as a seasoning, but strictly as medicine.

\section{Amelanchier alnifolia (Saskatoon berry, or serviceberry)}

Amelanchier alnifolia (Fig. 11) is an iconic fruit for Canadians, since the city of Saskatoon, in central Canada, is named after the anglicized Cree word "misâskwatômina" for the berries. The city's founder, John N. Lake, named it "Saskatoon" in 1882 after he had tasted a handful of the sweet purplish berries brought to him from along the riverbank [73]. The fleshy fruits are not true berries, but pomes, related in structure to apples and pears. There are well over a dozen other species of Amelanchier distributed across North America, most with good tasting fruits. Also known by the name of serviceberries, or sarvisberries, as well as shadberries, juneberries and chuckley pears, Saskatoon berries ripen in early summer, easily picked from short to tall spreading bushes. They grow in clusters and vary in quality but most are sweet and juicy, with relatively small seeds. They lend themselves to being dried in various ways, as well as being made into juice. They were, and still 
are enjoyed by Indigenous Peoples across North America, especially throughout the Great Plains and the Pacific Coastal region, and were commonly traded amongst different groups, especially in the form of dried cakes or loaves. The Blackfoot made "sausages" from the berries and fat stuffed into a length of intestine and boiled [74-76]. The berries were also traded widely to early explorers and fur traders, sometimes in cakes weighing as much as $6 \mathrm{~kg}$ (10 to 15 pounds), or as baskets or sacksful of loosely dried berries [31-33,42,74,75].

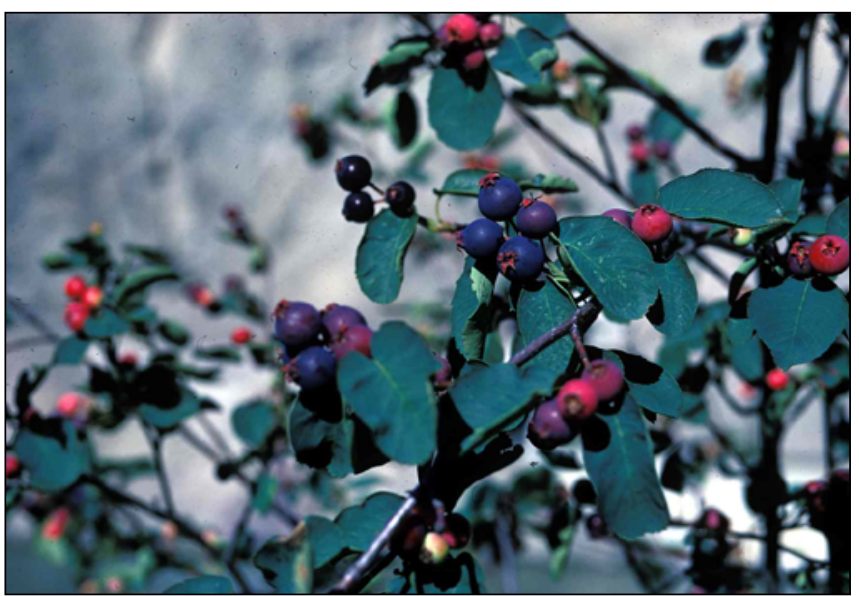

Fig. 11 Saskatoon berry, or serviceberry (Amelanchier alnifolia).

The berries were, in fact, quickly adopted by the French Canadian voyageurs and fur traders, traded to them by Métis (people of mixed ancestry, usually French-Canadian and Cree) and other Aboriginal Peoples, often in the form of an energyrich food known as pemmican (derived from the Cree word "pimîhkân", from "pimî" ("fat, grease"), made by pounding together dried Saskatoons (or other berries) with animal fat and dried meat (of bison, moose, elk or deer), into a nutritious and easily transported high energy loaf. There were many variations of pemmican; along the Fraser River, for example, people sometimes pounded together Saskatoon berries with dried salmon and deer fat to make a similar transportable food. Along with peas, beans, salt pork, maize, and sometimes wild-rice, pemmican sustained the fur traders on their travels and was also shipped north and sold to the major fur trading posts across the Prairies and in British Columbia. The famous explorer naturalists Lewis and Clark described these berries as "most delicious" when served as a winter food, eaten raw or broken into soup [16,21].

Across North America, wherever this shrub or its relatives grew, settlers adopted it as a favourite food, easily picked in quantity, sweet and tasty. As well as eating the berries fresh, they dried them as raisins or in cakes, canned or jammed them, and made them into pies and other desserts $[36,41]$. Susan Allison, a settler woman in southern British Columbia, reported from the mid-1870s, while she was living at Hope at the head of the Fraser River valley: "The Indian women used to gather and dry Saskatoons, so I did the same..." [7].

\section{Cranberries, or bog cranberries (Vaccinium oxycoccos and V. macrocarpon)}

These are small, tart fruits that grow on low vines in peat bog areas. Developing from small pink flowers with reflexed petals, these berries ripen in the fall. They are perhaps best known today as being served as sauce with turkey at Thanksgiving and Christmas, as well as for their deep red flavourful juice. These berries were, and are, harvested and used by First Peoples across North America, sometimes served mixed with grease or oil [33]. Due to their acidity, the berries have the advantage of being able to be stored for considerable periods of time in a cool place, or even under fresh water. There are related species in Europe, so that early traders and settlers from England and elsewhere encountering the berries were often already familiar with them. They were known as "fenberry" in England, then renamed "kranbeere" from Dutch, or "craneberries" because the resemblance of the blossoms to these birds. Another, related species, low-bush cranberry, or lingonberry (Vaccinium vitis-idaea), was also known to Europeans, especially Scandinavians, who immediately adopted it as settlers in the New World.

Captain John Smith described cranberries in 1614, but there is no direct evidence that Pilgrims ate cranberries with their turkey and bear meat at the first Thanksgiving dinner. As early as 1677, however, Massachusetts colonists sent ten bushels of wild-gathered cranberries (V. macrocarpon) along with maize and 3000 codfish to Charles II in England to appease his wrath at their coining of "Pine Tree shillings" without his consent $[9,77]$. Cranberries were recognized for their antiscorbutic properties, and American seafarers would often carry barrels of cranberries to be eaten by sailors to ward off scurvy, in the same way English "limeys" drank lemon juice [77].

By the mid-1800s, cranberries started to be cultivated, beginning in New Jersey in 1835, and spreading across the eastern United States. They were also harvested from the wild by Native Americans and Europeans and traded far and wide, down the Mississippi, and along the Pacific coast from the Fraser Valley to San Francisco. For example, the Hudson's Bay Company ventured into the cranberry trade in 1853, using modified First Nations trade networks utilized in the salmon trade for this new product (Vaccinium oxycoccos; Fig. 12). They converted barrels produced at their cooperage at Fort Langley in the Fraser Valley to kegs and casks and used a winnowing machine to wash the berries, which they obtained from local Coast Salish Peoples, then shipped to the booming city of San Francisco. "Over the next few years the Company developed the cranberry trade into one of its most successful and lucrative commercial undertakings on the coast" [37]. In February, 1854, the Company sent 250 barrels (6000 gallons) of cranberries

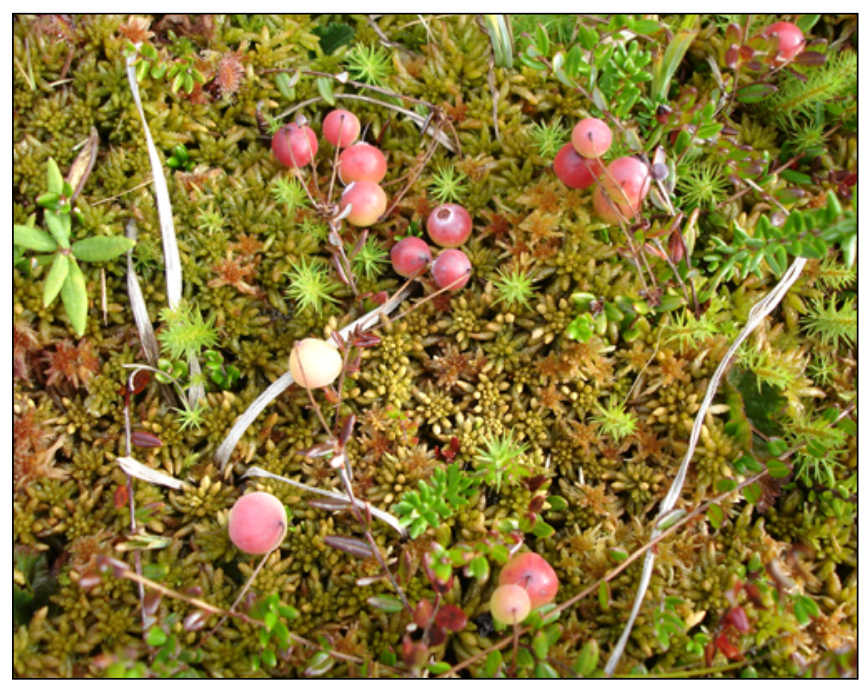

Fig. 12 Bog cranberries (Vaccinium oxycoccos). 
to San Francisco, and in 1855 they shipped cranberries to the Sandwich (Hawaiian) Islands [37,78].

The larger-fruited cranberry species, V. macrocarpon, was developed as a cultivar and transported from its original habitats west to Oregon and British Columbia and north to the Maritime Provinces and Quebec [77]. Today there are more than 100 varieties of cultivated cranberries, many named after families that first grew them [19]. Cranberries are a significant industry in many parts of North America. In 2010, for example, Wisconsin produced 3.96 million barrels of cranberries, representing nearly 60 percent of the crop in the United States. Cranberries have accounted for almost 85 percent of the total value of fruit production in Wisconsin, with nearly $\$ 300$ million annually in the past few years, representing approximately 3400 jobs [79].

\section{Discussion}

It is interesting to speculate as to the reasons why some plant foods of Indigenous Peoples were readily adopted by European newcomers and why others were ignored or rejected. Theodoratus [41], referring to use of indigenous foods by Europeans in the Upper Skagit River Valley of Washington stage, suggests a wide spectrum of influences: "Acceptance or rejection was correlated with whether the settlers were previously familiar with specific plants in their places of origin, patterns of the sexual division of labor, family structure, settlement patterns, ethnocentrism, food color and taste preferences, size and shape of the parts of the plant used as food in relation to concepts of economic value and even agricultural tool technology. Other factors include patterns of international trade and politics, logging practice, and ecological changes in the Upper Skagit Valley".

Familiarity certainly seems to be a good determinant of whether a "new" food will be adopted or not. For example, many Europeans were familiar with bakeapple, or cloudberry (Rubus chamaemorus; known as "molteberry" in Norway, maroshka in Russia, and avrons in Scotland) [19]. Europeans ate these berries fresh, preserved them and made them into liqueur. It is not surprising then, that, when they encountered these berries in their new surroundings, they continued to use them. The same could be argued for lingonberries or mountain cranberries (Vaccinium vitis-idaea), various species of currants and gooseberries (Ribes spp.), wild raspberries (Rubus idaeus L.), wild rose hips (Rosa spp.), and wild strawberries (Fragaria spp.). Another example is cow-parsnip (Heracleum maximum), whose European counterpart was formerly an ingredient in borscht in Eastern Europe, with the name "barszcz" in Polish [80], and which was eaten by those familiar with it.

On the other hand, few newcomers were used to eating the cambium and inner bark of trees $[33,81]$, although Scandinavians were known to have eaten it in the past [82]. Sometimes, too, foods took a long time to be adopted. Walker [19] points out that settlers in eastern North America first ploughed under wild raspberry bushes to clear land for agriculture, and that it wasn't until the 1830s that they became important as a crop. In a study on past and recent wild food use in the Skagit Valley of Washington State, Theodoratus mentions that wild Ribes species, both gooseberries and currants, were "rarely eaten" by the European settlers, and neither were red elderberries (Sambucus racemosa) [41]. In general, the more sour or bitter fruits were adopted only with the input of sugar, honey and other sweeteners. Oregon grapes (Mahonia spp.), elderberries (Sambucus spp.), Pacific crabapples (Malus fusca), highbush cranberries (Viburnum spp.) and wild grapes (Vitis spp.) fall into this category.

As well as adopting the actual foods, wild species of plants, especially berries, have been used over the past century or more as a source of genetic material for plant breeding. Soft fruit breeders of Ribes (black currants and gooseberries) and Rubus (raspberries, blackberries) study North American congeneric species in the search for genes that either confer resistance to a number of pest and disease problems or that improve physiological traits, such as better cold resistance [83]. Other wild plants are used in breeding programs to help improve their cultivated relatives by broadening the genetic base of cultivated plants. These include, for example, wild-rice (Zizania spp.), wild plums (Prunus spp.) and Fragaria spp. (strawberries) [42,84]. Tab. 3 lists some examples of native North American species used in plant breeding programs for improved crops.

Some of the plants that Native North Americans consumed, while not initially prized by colonists have found modern uses. For example, although North American grape species are far less palatable than the European grape (Vitis vinifera), the North American species were found to be incredibly resistant to the Phylloxera louse that ravaged European orchards in the 19th century. Used as rootstocks, they conferred resistance, and thus saved the wine industry. These various grape species have also been used to create hybrids with the European grape [85] that have novel flavours, as well as improved resistance to a number of common viruses, pests and diseases. Another plant used in a similar capacity is Pacific crabapple (Malus fusca). Because it is a tree that tolerates waterlogged soils and has some resistance to certain pests, it is sometimes used as a rootstock to support grafts of various domesticated apple varieties [86].

Many wild plant species remain important to the present day not only for individual harvesting and consumption but on a commercial scale. For example, harvesting of blueberries, originally based on wild growing species, transitioned starting in the early 1900s to large-scale cultivation, and lowbush blueberry is grown commercially in Maine, Quebec and Atlantic Canada generating (as of 2008) about $\$ 85$ million in Canada and between $\$ 75-100$ million a year in US [19]. Earlier economic figures for other native North American edible plant products in the United States economy were provided by Prescott-Allen and Prescott-Allen [51]: pecans (Carya illinoiensis; \$22 million per year), pine nuts (Pinus spp. - Fig. 13; $\$ 800000$ per year), lingonberries (Vaccinium vitis-idaea; $\$ 3000$ per year), maple sugar and syrup (Acer saccharum; $\$ 23$ million per year), wild-rice (Zizania spp. - Fig. 13; \$3 million per year) and edible seaweeds (Palmaria palmata, Porphyra spp., and other spp.; $\$ 900000$ per year). In addition, other edible species have become economically important through being incorporated into horticulture as edible landscaping and for their ornamental value. These include: salal (Gaultheria shallon), Oregon-grape (Mahonia spp.), Saskatoonberry (Amelanchier alnifolia), edible camas (Camassia spp.), evergreen huckleberry (Vaccinium ovatum), lingonberry (Vaccinium vitis-idaea), red-flowering currant (Ribes sanguineum), and kinnikinnick (Arctostaphylos uva-ursi). Some of these species are also components in ethnoecological restoration projects [87].

As well as the actual harvesting and use of edible wild plants, the newcomers, at least in some cases, came to appreciate some of the associated knowledge of these plants and how 
Tab. 3 Some examples of native North American species used in plant breeding programs for improved crops.

Amelanchier alnifolia (Nutt.) Nutt. ex M. Roem.

(saskatoonberry); Rosaceae

Corylus americana Walter (American hazelnut), Corylus

cornuta Marsh. (beaked hazelnut); Betulaceae

Fragaria chiloensis (L.) Duschesne, F. virginiana Duchesne

(wild strawberries); Rosaceae

Helianthus annuus L. (wild sunflower); Asteraceae

Malus fusca (Raf.) C. K. Schneid. (Pacific crabapple);

Rosaceae

Physalis pruinosa L. (ground-cherry); Solanaceae

Prunus angustifolia Marsh. and other Prunus spp. (wild

plums); Rosaceae

Ribes divaricatum Dougl., $R$. hirtellum Michx. (wild

gooseberries); Grossulariaceae

Rubus idaeus L., R. occidentalis L. and others (wild

raspberries); Rosaceae

Rubus allegheniensis Porter, R. ursinus Cham. \& Schlecht (wild blackberries); Rosaceae

Vaccinium corymbosum L., V. angustifolium Ait. and others (wild blueberries); Ericaceae

Vaccinium macrocarpon Ait. (bog cranberry); Ericaceae

Vitis labrusca L., V. rotundifolia Michx. (wild grapes);

Vitaceae
High producing cultivars have been developed, used commercially in jams $\quad[30,33,128]$ and syrups.

Corylus X (filbert cultivars; sometimes including European species).

Fragaria X (strawberry cultivars; sometimes including European species).

$[42,84,125]$

Helianthus annuus L. (sunflower cultivars).

Rootstocks for Malus domestica L. (apples), and genetic material for breeding.

Physalis cultivars (ground-cherry).

Prunus domestica L. (plum cultivars; sometimes including European species).

Ribes X (gooseberry cultivars; sometimes including European species).

Rubus idaeus L. (cultivated raspberry; sometimes including European species).

Rubus X (blackberry and hybrids - loganberry, boysenberry, cascadeberry, teyberry and others).

Vaccinium X (blueberry cultivars).

Vaccinium macrocarpon Ait. (cranberry cultivars).

Rootstocks for Vitis vinifera L. (European grapes). they could be enhanced and managed for productivity. This included learning practices of burning over areas to create ideal conditions for a number of these species. For example, explorer Samuel Hearne noted in 1795: "Strawberries, and those of a considerable size and excellent flavor, are found as far North as Churchill River, and what is most remarkable, they are frequently known to be more plentiful in such places as have formerly been set on fire" $[19,40]$.

Despite the numerous examples of newcomers using Indigenous plant foods, often they were disdainful of Indigenous Peoples' food, and rather than adopting the native foods in a major way, they set about trying to change Indigenous Peoples' diets towards European and marketed foods. This was undertaken in many ways, especially through the residential schools

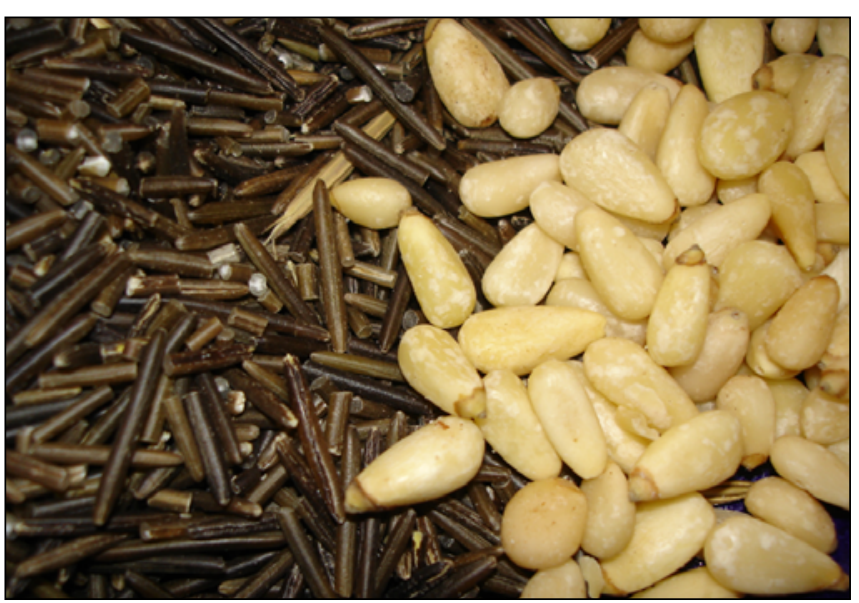

Fig. 13 Wild-rice (Zizania aquatica) and pinyon pine seeds (Pinus edulis), as sold in local markets. systems in many parts of North America, in which children were taken from their homes and placed in government and church sponsored boarding schools where they were trained in the ways of the newcomers and given institutional food, little of it from the traditions of the children's own cultures. After many years, children returned to their home communities, often having lost the preference for their ancestral foods, as well as the knowledge of how to harvest and process these foods [88]. Alienating children and youth from their traditional food was accompanied by restricting Indigenous Peoples' access to their food gathering areas through land appropriation and habitat destruction [88].

Nevertheless, the exchanges of food traditions that occurred between the Indigenous Peoples and the newcomers to North America represent an important example of how knowledge is transmitted from group to group, as well as how people are able to learn new information and adapt themselves to new places through adopting new foodways. Often, these exchanges are facilitated by intermediaries - individuals, almost always bilingual, who are familiar with two or more different cultures and can introduce new foods and other products from one culture to the other. Frequently, it was women who performed such roles, sometimes by marrying into the new culture and bringing the foods and cooking skills from their original culture with them. In other cases, it was the children of these women. The Métis people represent such a group. They are the descendants of Indigenous mothers and Caucasian fathers, usually French-Canadian traders known as voyageurs. Métis often carry the knowledge, skills and traditions of their Indigenous foremothers, including in their use of edible wild plants such as cloudberries, or bakeapples [89] and wild-rice, and this knowledge makes them particularly resilient. Shifts in food use and food preferences have occurred frequently amongst 
different populations and across the generations over time, and this is an on-going process. There are both advantages and dangers in these shifts. Sometimes, as new foods are adopted, older foods and varieties are lost, along with the knowledge surrounding their use - of harvesting and processing - and their cultural aspects as well [1].

\section{Conclusions}

History has shown that those people who are flexible in their outlook, and adaptable and resilient in the face of change, have the best chance of survival and success. A corollary to this is that a broad spectrum of knowledge and skills can provide people with more options for survival. Certainly, the First Peoples of North America served to supplement the knowledge and skills of the European newcomers, whether they were explorers, traders or settlers, with new and locally relevant knowledge and skills, particularly in the knowledge and use of new foods in their traditional territories. In many documented cases, it was the knowledge and skills of Indigenous hosts that enabled the newcomers' survival, whether by providing them with needed food such as wild-rice, camas bulbs, or berries, or by teaching them how to recognize, harvest and process these foods themselves. The survival value of these Indigenous foods is reflected in a number of publications focusing on wilderness survival and emergency foods (cf. [28,90-92]).

It is in some senses ironic that these very Indigenous foods that have sustained large aboriginal populations for millennia and have sustained many people of a variety of backgrounds in emergency situations, have, within just a few generations, been subsumed by imported and marketed foods, and many are virtually forgotten today, especially by those of younger generations. This is true for Indigenous Peoples' foods in North America, but also for foods of Indigenous Peoples in many parts of the world [93]. Today, only a very few Indigenous North American plant foods are known widely and feature as day-to-day foods of North Americans or peoples in Europe and elsewhere. We have provided examples of some of these, for example wild-rice, maple syrup and cranberries. The vast majority of species once featured in daily diets across North America are all but lost, to the detriment of people's health and cultural identity [1].

Fortunately, there are still some Indigenous Peoples practicing their local food traditions, and there is growing general interest, with the "hundred-mile diet", and the Slow Food Movement, in renewing some of these endangered foods, and rekindling their use within a modern day context [13,94,95]. These efforts are assisted by an interest of some in new and diverse foods, and foods that are healthy and nutritious, and reflect history and ethnicity. Many North American Indigenous foods are exotic and flavourful enough to fit these requirements, and, at least for some, they will continue to contribute to the health and enjoyment of many of us, Indigenous and non-Indigenous alike.

\section{Acknowledgements}

The authors are grateful to Łukasz Łuczaj and to unknown reviewers for their comments and suggestions. We also acknowledge Pamela Spalding for her help with editing and formatting the manuscript.

\section{References}

1. Nabhan GP, Rood A. Renewing America's food traditions (RAFT): bringing cultural and culinary mainstays of the past into the new millennium. Flagstaff AZ: Center for Sustainable Environments at Northern Arizona University; 2004.

2. Moerman D. Native American ethnobotany. A database of foods, drugs, dyes and fibers of Native American peoples, derived from plants [Internet]. The University of Michigan-Dearborn. 2003 [cited 2012 Aug 15]; Available from: http://herb.umd.umich.edu/

3. Fernald ML, Kinsey AC. Edible wild plants of eastern North America. New York NY: Harper; 1958.

4. Gibbons E. Stalking the wild asparagus. New York NY: D. McKay Co.; 1962.

5. Gaertner EE. The history and use of milkweed (Asclepias syriaca L.). Econ Bot. 1979;33(2):119-123. http://dx.doi.org/10.1007/BF02858278

6. Gaertner EE. Reap without sowing: wild food from nature's cornucopia. Burnstown: General Store Publishing House; 1995.

7. Szczawinski AF, Turner NJ. Wild green vegetables of Canada. Ottawa: National Museum of Natural Sciences; 1980. (Edible wild plants of Canada; vol 4).

8. Turner NJ, Szczawinski AF. Wild coffee and tea substitutes of Canada. Ottawa: National Museum of Natural Sciences; 1978. (Edible wild plants of Canada; vol 2).

9. Turner NJ, Szczawinski AF. Edible wild fruits and nuts of Canada. Ottawa: National Museum of Natural Sciences; 1979. (Edible wild plants of Canada; vol 3).

10. Thayer $S$. Nature's garden: a guide to identifying, harvesting, and preparing edible wild plants. Birchwood WI: Forager's Harvest; 2010.

11. Thayer $\mathrm{S}$. The forager's harvest: a guide to identifying, harvesting, and preparing edible wild plants. Ogema WI: Forager's Harvest; 2006.

12. Kallas J. Edible wild plants: wild foods from dirt to plate. Layton UT: Gibbs Smith; 2010.

13. Slow food foundation for biodiversity [Internet]. Slow food presidia. 2012 [cited 2012 Sep 16]; Available from: http://www.slowfoodfoundation.com/ pagine/eng/presidi/cerca_presidi.lasso?-id_pg=11

14. Turner NJ. Plants of the Nootka Sound Indians as recorded by Captain Cook. Sound Heritage. 1978;7(1):78-87.

15. Lamb WK, editor. The letters and journals of Simon Fraser, 1806-1808. Toronto: Macmillan; 1960.

16. Cutright PR. Lewis and Clark: pioneering naturalists. Urbana: University of Illinois Press; 1969.

17. Ormsby M, editor. A pioneer gentlewoman in British Columbia: the recollections of Susan Allison. Vancouver: University of British Columbia Press; 1976.

18. Arnason T, Hebda RJ, Johns T. Use of plants for food and medicine by Native Peoples of eastern Canada. Can J Bot. 1981;59(11):2189-2325. http://dx.doi.org/10.1139/b81-287

19. Walker M. Wild plants of Eastern Canada: identifying, harvesting and using: includes recipes \& medicinal uses. Halifax: Nimbus Pub; 2008.

20. Turner NJ, Brown CH. Grass, hay, and weedy growth: utility and semantics of interior Salish botanical terms. In: Gerdts DB, Matthewson L, editors. Studies in Salish linguistics in honor of M. Dale Kinkade. Missoula MT: University of Montana Press; 2004. p. 410-428. (Occasional papers in Linguistics; vol 17).

21. Marion A, Wittrock GL. Food Plants of the Indians. J NY Bot Gard. 1942;43(507):57-71.

22. Anderson MK. Tending the wild: Native American knowledge and the management of California's natural resources. Berkeley CA: University of California Press; 2005.

23. Boyd R. Indians, fire, and the land in the Pacific Northwest. Corvallis OR: Oregon State University Press; 1999.

24. Deur D, Turner NJ, editors. Keeping it living: traditions of plant use 
and cultivation on the Northwest Coast of North America. Seattle WA: University of Washington Press; 2005.

25. British Columbia. Papers connected with the Indian land question, 1850-1875. Victoria: Richard Wolfenden; 1875.

26. Brown R. The miscellaneous botanical works of Robert Brown. London: R. Hardwicke; 1866. (vol 1,2).

27. Chesnut VK. Plants used by the Indians of Mendocino County, California. Washington: Government Printing Office; 1902. (Contributions from the United States National Herbarium; vol 7).

28. Heller CA. Wild edible and poisonous plants of Alaska. Darby PA: Diane Publishing; 1993.

29. Turner NJ, Thompson LC, Thompson MT, York AZ. Thompson ethnobotany: knowledge and usage of plants by the Thompson Indians of British Columbia. Victoria: Royal British Columbia Museum; 1990. (Royal British Columbia Museum Memoir; vol 3).

30. Waugh FW. Iroquis foods and food preparation. Ottawa: Government Printing Bureau; 1916. (Geological Survey of Canada: Anthropological series, Memoir; vol 12).

31. Turner NJ. Food plants of interior First Peoples. 2nd ed. Victoria: Royal British Columbia Museum; 2007.

32. Turner NJ. Food plants of coastal First Peoples. Victoria: Royal British Columbia Museum; 2010.

33. Kuhnlein HV, Turner NJ. Traditional plant foods of Canadian indigenous peoples: nutrition, botany, and use. In: Katz S, editor. Food and nutrition in history and anthropology. Philadelphia PA: Gordon and Breach Sicnece Publishers; 1991. (vol 8).

34. Walker M. Harvesting the northern wild: a guide to traditional and contemporary uses of edible forest plants of the Northwest Territories. Yellowknife: Outcrop; 1984.

35. Hammett $\mathrm{J}$. The shapes of adaptation: historical ecology of anthropogenic landscapes in the southeastern United States. Landsc Ecol. 1992;7(2):121135. http://dx.doi.org/10.1007/BF02418943

36. Christy JA, Kimpo A, Marttala V, Gaddis PK, Christy NL. Urbanizing Flora of Portland, Oregon, 1806-2008. Native Plant Society of Oregon Occasional Paper. 2009;3:1-319.

37. Mackie RS. Colonial land, Indian labour and company capital: The economy of Vancouver Island, 1849-1858 [Master thesis]. Victoria: University of Victoria; 1984.

38. Turner NJ, Loewen DC. The original "free trade": exchange of botanical products and associated plant knowledge in Northwestern North America. Anthropologica. 1989;40(1).

39. Richardson J. (1823) Botanical appendix. In: Franklin J, editor. Narrative of a journey to the shores of the Polar Sea in the years 1819, 20, 21, and 22. London: J. M. Dent and Sons; 1924. p. 729-668. (Appendix 7).

40. Hearne S. A journey from Prince of Wales's fort in Hudson's Bay to the northern ocean, in the years $1769,1770,1771$, and 1772 . Toronto: The Champlain Society; 1911.

41. Theodoratus RJ. Loss transfer and reintroduction in the use of wild plant foods in the Upper Skagit Valley. Northwest Anthropol Res Notes. 1989;23(1):35-52.

42. Kindscher K. Edible wild plants of the prairie: an ethnobotanical guide. Lawrence: University Press of Kansas; 1987.

43. Darby MC. The intensification of wapato (Sagittaria latifolia) by the Chinookan People of the Lower Columbia River. In: Deur D, Turner NJ, editors. Keeping it living: traditions of plant use and cultivation on the northwest coast of North America. Seattle WA: University of Washington Press; 2005. p. 194-217.

44. Turner NJ. The ethnobotany of edible seaweed (Porphyra abbottae and related species; Rhodophyta: Bangiales) and its use by First Nations on the Pacific Coast of Canada. Can J Bot. 2003;81(4):283-293. http://dx.doi. org/10.1139/b03-029

45. Turner NJ. Ethnobotany of the Hesquiat Indians of Vancouver Island. Victoria: British Columbia Provincial Museum; 1982. (Cultural Recovery
Paper; vol 2).

46. Beckwith BR. The queen root of this clime: ethnoecological investigations of blue camas (Camassia quamash, C. leichtlinii; Liliaceae) landscapes on southern Vancouver Island, British Columbia [PhD thesis]. Victoria: University of Victoria; 2004.

47. Gibbs G. Tribes of western Washington and northwestern Oregon. Washington: Government Printing Office; 1877.

48. Ommer RE, Turner NJ. Informal rural economies in history. Labour. 2004;53:127-157.

49. Erichsen-Brown C. Use of plants for the past 500 years. Aurora: Breezy Creeks Press; 1979.

50. Rousseau J. Le folklore botanique de l'Ile aux Coudres. Contributions de l'Institut botanique l'Universite de Montreal. 1945;55:7-72.

51. Prescott-Allen C, Prescott-Allen R. The first resource: wild species in the North American economy. New Haven CT: Yale University Press; 1986.

52. Hartzell H. The yew tree: a thousand whispers (biography of a species). Eugene OR: Hulogosi; 1991.

53. Medsger O. Edible wild plants. New York NY: Macmillan; 1939.

54. Munro DB, Small E. Vegetables of Canada. National Research Council of Canada Press; 1997.

55. von Aderkas P. Economic history of ostrich fern, Matteuccia struthiopteris, the edible fiddlehead. Econ Bot. 1984;38(1):14-23. http://dx.doi. org/10.1007/BF02904412

56. Fisher P. History of New Brunswick. St. John: Historical Society of New Brunswick; 1921.

57. The PLANTS database [Internet]. USDA. 2012 [cited 2012 Aug 31]; Available from: http://plants.usda.gov

58. Zizania L. wildrice [Internet]. USDA. 2012 [cited 2012 Aug 31]; Available from: http://plants.usda.gov/java/profile?symbol=ZIZAN

59. Smith HH. Ethnobotany of the Ojibwe Indians. Bulletin of the Public Museum of Milwaukee. 1932;4:327-525.

60. Smith HH. Ethnobotany of the forest Potawatomi. Bulletin of the Public Museum of Milwaukee. 1933;7:1-230.

61. Reagan AB. Plants used by the Hoh and Quileute Indians. Trans Kans Acad Sci. 1934;37:55-70. http://dx.doi.org/10.2307/3625277

62. Densmore F. Uses of plants by the Chippewa Indians. Washington: Bureau of American Ethnology; 1928. (vol 44).

63. Stowe GC. Plants used by the Chippewa. Wisconsin Archaeologist. 1940;21:8-13.

64. Dore WG. A wild ground-bean, Amphicarpa, for the garden. Greenhouse Garden Grass. 1970;9(2):7-11.

65. Jenks AE. The wild rice gatherers of the upper lakes: a study in American primitive economics [Internet]. Wisconsin Historical Society. 1900 [cited 2012 Aug 15]; Available from: http://www.wisconsinhistory.org/ turningpoints/search.asp?id=1065

66. Morton JF. Wild rice - a promising gourmet crop for the everglades. Annu Meet Fla State Hort Soc. 1980;93:273-278.

67. Nabhan GP. Gathering the desert. Tucson AZ: University of Arizona Press; 1985.

68. Henshaw HW. Indian origin of maple sugar. Am Anthropol. 1890;3(4):341-352. http://dx.doi.org/10.2307/658239

69. Eagleson J, Hasner R. The maple syrup book. Erin: Boston Mills Press; 2006.

70. Bainbridge DA. The rise of agriculture: a new perspective. Ambio. 1985;14(3):148-151.

71. Niethammer CJ. American Indian food and lore. New York NY: Macmillan; 1974.

72. Baxter BN. An oral history of the American chestnut in southern Appalachia [Master thesis]. Chattanooga TN: University of Tennessee; 2009.

73. Douglas R. Meaning of Canadian city names. Ottawa: F. A. Acland; 1922.

74. Hungry-Wolf A. Pikunni history and culture. Skookumchuck: Good Medicine Foundation; 2006. (The Blackfoot Papers; vol 1).

75. Hellson JC, Gadd M. Ethnobotany of the Blackfoot Indians. Ottawa: 
National Museums of Canada; 1974. (National Museum of Man Mercury Series; vol 19).

76. Scott-Brown J. Stoney ethnobotany: an indication of cultural change [Master thesis]. Calgary: University of Calgary; 1977.

77. Seelig RA. October. Fruit and vegetable facts and pointers: cranberries. Washington: United Fresh Fruit and Vegetable Association; 1974.

78. MacLachlan M, Suttles WP. The Fort Langley journals, 1827-1830. Vancouver: UBC Press; 1998.

79. Wisconsin state cranberry growers association growing Wisconsin cranberries, growing Wisconsin's economy [Internet]. 2010 [cited 2012 Aug 31]; Available from: http://www.wiscran.org/about_cranberries_0002/ Economic_Impact_0088.html

80. Turner NJ, Łuczaj ŁJ, Migliorini P, Pieroni A, Dreon AL, Sacchetti LE, et al. Edible and tended wild plants, traditional ecological knowledge and agroecology. Crit Rev Plant Sci. 2011;30(1-2):198-225. http://dx.doi.org /10.1080/07352689.2011.554492

81. Dilbone M. The nutritious springtime candy of people and animals in British Columbia: Lodgepole pine cambium (Pinus contorta Douglas ex Louden var. latifolia Engelm. ex S. Watson) [Master thesis]. Victoria: University of Victoria; 2011.

82. Ostlund L, Ahlberg L, Zackrisson O, Bergman I, Arno S. Bark-peeling, food stress and tree spirits - the use of pine inner bark for food in Scandinavia and North America. J Ethnobiol. 2009;29(1):94-112. http://dx.doi. org/10.2993/0278-0771-29.1.94

83. Finn CE, Knight VH. What's going on in the world of Rubus breeding? Acta Hortic. 2002;585:31-38.

84. Lenne JM, Wood D. Plant diseases and the use of wild germplasm. Annu Rev Phytopathol. 1991;29(1):35-63. http://dx.doi.org/10.1146/annurev. py.29.090191.000343

85. Pavloušek P. Screening of rootstock hybrids with Vitis cinerea Arnold for Phylloxera resistance. Cent Eur J Biol. 2012;7(4):708-719. http://dx.doi. org/10.2478/s11535-012-0062-Z

86. Routson KJ. Malus diversity in wild and agricultural ecosystems. Tucson AZ: Univeristy of Arizona; 2012.

87. Senos R, Lake F, Turner NJ, Martinez D. Traditional ecological knowledge and restoration practice in the Pacific Northwest. In: Apostol D, editor. Encyclopedia for restoration of Pacific Northwest ecosystems. Washington: Island Press; 2006. p. 393-426.

88. Turner NJ, Turner KL. Where our women used to get the food: cumulative effects and loss of ethnobotanical knowledge and practice; case study from coastal British Columbia. Botany. 2008;86(2):103-115.

89. Karst AL, Turner NJ. Local ecological knowledge and importance of bakeapple (Rubus chamaemorus L.) in a southeast Labrador Métis Community. Ethnobiology Letters. 2011;2:6-18.

90. Drury HF, Smith SG. Alaskan wild plants as an emergency food source. In: Science in Alaska. Proceedings of the 4th Alaskan Science Conference. Juneau AK: American Association for the Advancement Of Science; 1953. p. 255-159.

91. Eidlitz K. Food and emergency food in the circumpolar area. Uppsala: Almqvist and Wiksells; 1969. (Studia Ethnographica Upsaliensia; vol 32).

92. Porsild AE. Emergency food in arctic Canada. Ottawa: National Museum of Canada; 1945. (vol 45-1).

93. Kuhnlein HV, Erasmus B, Spigelski D, editors. Indigenous Peoples' food systems: the many dimensions of culture, diversity and environment for nutrition and health. Rome: FAO; 2009.

94. Petrini C. Buono, pulito e giusto: principî di nuova gastronomia. Torino: Einaudi; 2005.

95. Parrish C., Turner NJ, Solberg SM, editors. Resetting the kitchen table: food security, culture, health and resilience in coastal communities. New York NY: Nova Science Publishers; 2007.

96. Duke JA. CRC handbook of medicinal herbs. Boca Raton FL: CRC Press; 1985.

97. Foster S. Black cohosh: a literature review. HerbalGram. 1999;45:35-50.
98. Turner NJ. Ethnobotany of coniferous trees in Thompson and Lillooet interior salish of British Columbia. Econ Bot. 1988;42(2):177-194. http:// dx.doi.org/10.1007/BF02858918

99. Lantz T, Swerhun K, Turner NJ. Devil's club (Oplopanax horridus): an ethnobotanical review. HerbalGram. 2004;62(2):33-48.

100. Meijer W. Podophyllum peltatum - may apple a potential new cash-crop plant of eastern North America. Econ Bot. 1974;28(1):68-72. http://dx.doi. org/10.1007/BF02861382

101. Millspaugh CF. American medicinal plants: an illustrated and descriptive guide to plants indigenous to and naturalized in the United States which are used in medic. New York: Courier Dover Publications; 1974.

102. Gunther E. Ethnobotany of western Washington: the knowledge and use of indigenous plants by Native American. Seattle WA: University of Washington Press; 1973.

103. Foster S. Forest pharmacy: medicinal plants in American forests. Durham NC: Forest History Society; 1995.

104. Duke JA. The green pharmacy: the ultimate compendium of natural remedies from the world's foremost authority on healing herbs. New York: St. Martin's Paperbacks; 1997.

105. Madlener JC. The seavegetable book. New York: C. N. Potter; 1977.

106. Morgan KC, Wright JLC, Simpson FJ. Review of chemical constituents of the red alga Palmaria palmata (dulse). Econ Bot. 1980;34(1):27-50. http:// dx.doi.org/10.1007/BF02859553

107. Turner NJ. Economic importance of black tree lichen (Bryoria fremontii) to the Indians of western North America. Econ Bot. 1977;31(4):461-470. http://dx.doi.org/10.1007/BF02912559

108. Crawford S. Ethnolichenology of Bryoria fremontii: wisdom of elders, population ecology, and nutritional chemistry [Master thesis]. Victoria: University of Victoria; 2007.

109. Franklin J. Narrative of a journey to the shores of the Polar Sea in the years 1819, 20, 21, and 22. London: J. M. Dent and Sons; 1924.

110. Marles RJ, Clavelle C, Monteleone L, Tays N, Burns D. Aboriginal plant use in Canada’s northwest boreal forest. Vancouver: UBC Press; 2000.

111. Menzies C. Ecological knowledge, subsistence, and livelihood practices: the case of the pine mushroom harvest in northwestern British Columbia. In: Menzies C, editor. Traditional ecological knowledge and natural resource management. Lincoln NE: University of Nebraska Press; 2011.

112. Gilmore MR. The ground bean and its uses. Indian Notes. 1925;2:178-182.

113. Lanner RM. The piñon pine: a natural and cultural history. Reno NV: University of Nevada Press; 1981.

114. Moore MI. Eastern white pine and eastern white cedar. Forest Chron. 1978;54(4):222-223.

115. Yanovsky E. Food plants of the North American Indians. Washington: U. S. Department of Agriculture; 1936. (Miscellaneous Publication; vol 237).

116. Graham TO. A possible new commercial fruit crop (Amelanchier alnifolia). Paper prepared for the annual meeting, Canadian Society for Horticultural Science. Guelph: University of Guelph; 1977.

117.Zatylny AM, St-Pierre RG. Revised international registry of cultivars and germplasm of the genus Amelanchier. Small Fruits Rev. 2003;2(1):51-80.

118. Havard V. Food plants of the North American Indians. J Torrey Bot Soc. 1895;22(3):98-123. http://dx.doi.org/10.2307/2477757

119. Beardsley G. The groundnut as used by the Indians of eastern North America. Papers of the Michigan Academy of Science, Arts, and Letters. 1939;25:507-515.

120. Turner NJ, Kuhnlein HV. Two important "root" foods of the Northwest Coast Indians: springbank clover (Trifolium wormskioldii) and Pacific silverweed (Potentilla anserina ssp. pacified). Econ Bot. 1982;36(4):411-432. http://dx.doi.org/10.1007/BF02862700

121. Abrams MD, Nowacki GJ. Native Americans as active and passive promoters of mast and fruit trees in the eastern USA. Holocene. 2008;18(7):11231137. http://dx.doi.org/10.1177/0959683608095581

122. Battle HB. The domestic use of oil among the southern aborigines. Am Anthropol. 1922;24(2):171-182. http://dx.doi.org/10.1525/ 
aa.1922.24.2.02a00040

123. Talalay L, Keller DR, Munson PJ. Hickory nuts, walnuts, butternuts, and hazelnuts: observations and experiments relevant to their aboriginal exploitation in eastern North America. In: Munson PJ, editor. Experiments and observations in Aboriginal wild food utilization in eastern North America. Indianapolis IN: Indiana Historical Society; 1984. p. 171-182. [Prehistoric Research Series; vol 6(2)].

124. Hedrick UP, editor. Sturtevant's edible plants of the world. New York: Dover Publications; 1972.

125. Nicholson EB, Harrison SG, Masefield GB, Wallis M. The Oxford book of food plants. Oxford: Oxford University Press; 1969.
126. Hunn ES, Selam J. Nch'i-wána, "the Big River": mid-Columbia Indians and their land. Seattle WA: University of Washington Press; 1990.

127.von Aderkas P, Turner NJ. The North American guide to common poisonous plants and mushrooms: how to identify more than 200 toxic plants found in homes, gardens, and open spaces. Portland OR: Timber Press; 2009.

128. Johnston A. Plants and the Blackfoot. Lethbridge: Lethbridge Historical Society; 1987. (Occasional paper).

129. Blumenthal M, editor. The complete German commission E monographs: therapeutic guide to herbal medicines. Austin TX: American Botanical Council; 2000. 